THE CBC'S "SEVEN WONDERS OF CANADA": EXCLUSIONARY ASPECTS OF A

Debbie Starzynski, BA, University of New Hampshire, 1973

\author{
A Major Research Paper \\ presented to Ryerson University \\ in partial fulfillment of the requirements for the degree of \\ Master of Arts \\ in the program of \\ Immigration and Settlement Studies
}

Toronto, Ontario, Canada, 2009

(C) Debbie Starzynski 2009 


\section{Author's Declaration}

I hereby declare that I am the sole author of this major research paper.

I authorize Ryerson University to lend this paper to other institutions or individuals for the purpose of scholarly research.

Signature

I further authorize Ryerson University to reproduce this paper by photocopying or by other means, in total or part, at the request of other institutions or individuals for the purpose of scholarly research.

Signature 


\title{
THE CBC'S "SEVEN WONDERS OF CANADA: EXCLUSIONARY ASPECTS OF A PROJECT OF NATIONAL IDENTITY
}

A major research paper submitted in partial fulfillment of the requirements for the
Master of Arts degree in Immigration and Settlement Studies, Ryerson University, 2009

By Debbie Starzynski

\begin{abstract}
The topic of my major research paper is national identity in the context of cultural pluralism. The paper has as its goal a socio-cultural analysis of national belonging. Immigration policy as gateway has, historically, excluded certain groups from entry to the country; nationalisms have prevented some of those who have gained entry to the country from gaining entry to the nation. I argue that the CBC's "Seven Wonders of Canada" campaign is one such nationalism, revealing nationalist tropes which include the cultural centre's longstanding tradition of identifying with the landscape and its more recent tradition of identifying with multicultural ideology - in its construction of national identity. Ultimately, this paper demonstrates that the campaign reflects an a-historic notion of national identity in which both geography and multiculturalism are used by the cultural centre to exclude. The construction of an exclusionary notion of national identity is necessarily challenged by notions of cultural pluralism. In the context of imbalanced power relations, mainstream Canadians, the cosmopolite and the Other vie for a share of national space.
\end{abstract}

Key words: Canadian national identity, national belonging, nationalisms, CBC's "Seven Wonders of Canada", multiculturalism, cultural pluralism 


\section{ACKNOWLEDGEMENTS}

I acknowledge with great appreciation Dr. Fumia's supervision in the preparation of this major research paper. I thank her for her vision, constructive criticism and constant enthusiasm.

I thank Dr. Koc for his role in this major research paper as second reader. I had the pleasure of taking a course in the Immigration and Settlement Studies program taught by Dr. Koc; I thank him, also, for that great learning experience.

To my classmate and friend, Farishta Dinshaw, I am indebted. Her cheerful and heartfelt support in and outside of school is hugely appreciated. 
INTRODUCTION

METHODOLOGY

REVIEW OF THE LITERATURE

12

Nation, boundary, nationalisms and contestation

Perspectives on Canadian National Identity

White geography 21

Nationalist multiculturalism

The CBC /the "Seven Wonders of Canada" campaign participant

The popular vote: White geography

The final list: nationalist tropes and strategies

Reaction to the final list: "the people" and notions of centre/periphery

64

The campaign ends: the CBC's apology and my concluding comments 
List of appendices
A) Object of study list: "Seven Wonders of Canada" campaign material
B) Object of study list: Campaign Participants - responses to CBC campaign 


\section{Introduction}

Having known for some time that my major research paper would, in some form, address issues of national identity in the context of cultural pluralism, it was with great interest that I watched the $\mathrm{CBC}$ one evening in the spring of 2007 when Peter Mansbridge was promoting the "Seven Wonders of Canada" campaign. His use of the expression "Canadian-ness" convinced me that the campaign was a project of national identity and a phenomenon I wanted to research. The goal of my major research paper is to provide a socio-cultural analysis of national belonging, demonstrating that there is a cultural centre, of which the $\mathrm{CBC}$ is part, with the power to include and exclude. Insofar as my data is gathered from the CBC's "Seven Wonders of Canada" campaign and responses to it, I make my starting point a cursory description of the campaign itself. My introduction then continues with elucidation of my argument.

\section{The object of study}

Taking inspiration from the "New Seven Wonders of the World" project ${ }^{1}$, Ian Clayton, an associate producer at CBC's Radio Canada, is credited with the creation of the "Seven Wonders of Canada" campaign (campaign material \#1) ${ }^{2}$. Announced to the public on April 23, 2007, the campaign aspired "to generate conversation and excitement about the many unique and inspiring features of this country" (campaign material \#ii). The campaign was designed "to encourage a national dialogue about our country, not simply to come up with one definitive list" (campaign

\footnotetext{
${ }^{1}$ Bernard Weber, a Swiss-Canadian, and his NewOpenWorld Foundation sponsored this project with results announced on July, 7, 2007 in Madrid with the idea of updating current Seven Wonders of the World lists. This event, not to be confused with the "Seven Wonders of Canada" campaign, is commonly referred to as N7W. There is no abbreviation attached to the "Seven Wonders of Canada".

${ }^{2}$ The reference list for campaign material and participant response is located in the methodology section of the paper with rationale.
} 
material \#iii). In assisting participants to make appropriate nominations, the campaign organizers advised:

Maybe it has natural beauty. Perhaps it's because of the wildlife. It could be the people who live there ... The list of potential Canadian wonders is wide open. You can pick an awesome natural wonder, a beautiful building, that quirky little park at the end of your street, a rock shaped like your favourite prime minister, or even a regular weather phenomenon. Any physical feature in Canada could be a possibility. All we ask is that other Canadians be able to see it somehow. (campaign material \#iv)

The rules proscribed that criteria be met:

Essential 'Canadian-ness' - historically significant, character filled, valued Originality/uniqueness of the pitch and place Spectacular physical site or amazing human creation Ability to inspire Range within the final seven - diversity of location, type of wonder (campaign material \#v)

Participants were encouraged to share stories by calling Radio Canada and to nominate and vote online beginning May 14, 2007. Weekly updates were available on the radio during the "Sounds Like Canada" program and on television during "The National" news broadcast. The final list was arrived at in stages, each stage implicating more or less involvement from the panel of three judges. The "Seven Wonders" participants submitted 25,000 nominations from which the judges created a short list of 52. Online voting "played an important part" (campaign material \#iii) in reducing the list to fifteen, at which time sole authority was returned to the judges to determine the final seven for announcement on June 7, 2007. The issue of participant voting became a contentious one, many participants bitterly thinking that their votes should have had more influence. The judges' list is the official one but considerable acknowledgement is made in the campaign material of the list of seven determined by the popular vote. 


\section{My argument}

Borrowing from Ghassan Hage (1998) and several others, I argue that national identity is constructed by those in the cultural centre to maintain their very centricity. These constructions create racialized class differentiations and unfold in national space where some belong more than others. In undertaking the "Seven Wonders of Canada" campaign, the Canadian Broadcasting Company has revealed the promulgation of a particular "Canada" which supports the cultural centricity of Richard Gwyn's (1995) English-Canadians and Eva Mackey's (2002) CanadianCanadians. The "Seven Wonders of Canada" campaign reflects an a-historic, white/White ${ }^{3}$ notion of national identity which is necessarily challenged by the notion of cultural pluralism and multiculturalism's purported valuation of it. In my analysis of the campaign, I expose and critique two subjectivities. The popular vote reflects the longstanding attachment to the Canadian landscape as a means of establishing the parameters of belonging to the nation. The final list of seven "wonders" echoes multicultural strategies which officially "include", yet, in a practical sense, ultimately exclude. The campaign invites "Canadians" to participate but as will be discussed throughout the paper, the $\mathrm{CBC}$ notion of Canada and Canadian has parameters.

Much has been written on the topic of Canadian national identity, revealing overtly and covertly racialized nationalisms - from the Canada First Movement to current day multiculturalism. ${ }^{4}$ Projects of national identity attach meaning to ideology, values, people, geography, artifacts and monuments in a manner that suggests a larger meaning, one that binds a

\footnotetext{
${ }^{3}$ As in much of the literature, I use "white" in the sense of race and "White" somewhat less in the sense of race but rather in the sense of an essence, reflecting the cultural centre that all can ascribe to (Hage, 1998).

${ }^{4}$ Much of the literature rightly equates the concept of cultural pluralism with multiculturalism. Insofar as the notion of multiculturalism in the Canadian context goes beyond this literal meaning to include ideology and policy, I make this distinction in my major research paper. Cultural pluralism is used to denote just that and multiculturalism is used to denote ideology and policy.
} 
group of people together emotionally, philosophically and politically. If the nationalisms, which have sought to proscribe what it means to be "Canadian", are a longstanding reality, so, too, is cultural pluralism - thereby begging the question as to who is included in any notion of “Canadian”. Immigration policy, as argued by Mackey (2002) becomes a site of contestation: immigration/immigrants were essential for nation building activities yet were potentially detrimental to the construction of a "Canadian" national identity. The material needs of nation building prevailed, necessitating that certain measures be taken in the construction of a particular "Canadian" national identity by those in the centre - if they wanted to keep themselves so located (Mackey, 2002). Immigration policy as gateway has, historically, excluded certain groups from entry to the country; nationalisms have prevented some of those who have gained entry to the country from gaining entry to the nation. The cultural centre uses its power to marginalize and position, determining what place and space immigrants, as well as indigenous peoples and the French, may occupy. Mackey (2002) and Hage (1998) argue that the inclusion/exclusion paradigm represents a continuum, that exclusion is rarely absolute. Those in the cultural centre have the power/authority to determine who belongs in what space, to position the Other.

Cultural centricity is an essence which takes many normative forms; I argue that the $\mathrm{CBC}$ is one of them. The concept of essence is crucial to my argument that a campaign which purports to represent Canada and Canadians in fact excludes many Canadians. There is no black and white; no clear lines are drawn. Yet, what is clear is that there is an essence representing both the group of people who belong and those who do not. The paper that follows offers an analysis of cultural centricity and notions of exclusion reflected in the campaign, a campaign of national 
identity. Notions of contestation, noticeably absent in reaction to the campaign, are addressed. In my analysis, the work of the cultural centre to construct a self-serving national identity is countered by Rob Shields' (1991) sense of periphery as a crucial part of nationalist contestation. It is on the margins where perspective is clearer; he argues “... the view from the margin becomes the only determinant of universally-binding truth" (p.277). 


\section{Methodology}

\section{Research question}

This major research paper analyzes the phenomenon of national belonging as a site of contestation: the efforts of the cultural centre to maintain its position of power and the efforts of the periphery to interject new meanings of nation and is grounded in data attached to the CBC's "Seven Wonders of Canada" campaign.

\section{The data}

I became aware of the "Seven Wonders of Seven" campaign over a period of several weeks in the spring of 2007. It was "The National" CBC news programming where the campaign was introduced, updates on the voting were made available and the final list of seven was announced. My research, however, draws from internet websites, including the type of website referred to as weblog (blog), created by blog authors (bloggers). Bloggers link to other blogs to share information; these links and the blogs connected by them comprise the blogosphere. (Golitsinski, 2007). Consideration is given at this point to blog sites as a source of research data.

Blog use has grown exponentially since the technology was introduced in 1999. Blogger, one such blog publishing tool, had 2,300 registered users at the end of 1999 and 117,970 by January 2001 - representing a 5,029 per cent increase in thirteen months (Herring et al., 2005, p.2). Technorati, a blog search service, estimated in 2006 that the blogosphere was then sixty times larger than it had been in 2003 (Herring et al., 2005, p.2). Golitsinski (2007) demonstrates the viability of blogs in referencing a Pew Internet study in the United States in which 27 per cent of the 20 million adults who use the internet are self-declared blog readers. Generally 
considered an easy, inexpensive tool of potential mass communication, the blogosphere is made possible by technology and often inspired by events in the news - man-made and natural. The CBC "Seven Wonders of Canada" campaign was one such event - inspiring on topic blogging in both internal and external, personal blog sites. Through communication networks, "blogs have the capacity to be virtual communities" (Sundar and Edwards cited in Golitsinski, 2007, p.1).

The blogging phenomenon has become a topic of scholarly research in terms of both content analysis and social network analysis (Herring et al., 2005). My research is neither content analysis nor social network analysis yet pays strict attention to who is saying what. The notion of blogosphere as concept is important insofar as it represents a "virtual community" or network that of necessity is not inclusive. Much of the campaign unfolded on-line and in English thereby excluding, as discussed in the "C $\mathrm{CBC} /$ campaign participant" section of the paper, certain groups of people. It is very much my argument that the $\mathrm{CBC}$ and the campaign represent a particular group of people, a "community", who have a nationalist sense of self and exclude the Other. The content/commentary at blog sites is crucial insofar as it provides qualitative data: ideological themes and socio-cultural meaning to support my argument throughout the paper.

\section{Data gathering}

Mackey (2002) discusses the difficulty many researches have in accessing the views of "ordinary people" on the topic of nationalism and her good fortune in being able to do so in her 
study of Canada 125 celebrations. ${ }^{5}$ Mackey (2002) notes that the very nature of the patriotic celebrations connected to "Canada 125"gave her easy access to people willing to talk on the subject of national identity. Paralleling Mackey's (2002) good fortune, I was able to locate a wealth of pertinent information in the internet. "CBC Seven Wonders of Canada", as a "google" search, yielded "about 107,000 results". I reviewed hundreds of websites (of the CBC, newspapers, tourist agencies, politicians and bloggers) - looking for pertinent commentary the "hits" became repetitive or unrelated and it appeared that nothing significant was to be gained by further search. At this point, I made the determination that representative and sufficient data had been gathered.

The data can be divided into two categories: campaign material and campaign participant responses. Campaign material is designated as the material created at $\mathrm{CBC}$ websites to promote the campaign and to provide progress reports. Campaign participant responses are designated as a response to the campaign from any source and include bloggers, newspaper articles and promotional material from a museum and travel commission. Shinsuke Nakajima, Junichi Tatemura, Yoichiro Hino, Yoshinori Hara and Katsumi Tanaka (2005) argue that a blog represents "conversation" rather than an archived document; I argue it is both as long as the URL (uniform resource locator) remains stable. Any data from the above-noted "google" search could potentially be included; data that did not further the discussion: geography as national identity and national identity as exclusionary - was excluded. This process yielded the following data

\footnotetext{
${ }^{5}$ Mackey had originally planned to research Canadian celebrations of the Columbus Quincentenary in 1992 until concomitant controversy made the Canadian government reconsider its plans. The Canadian government decided on Canada's $125^{\text {th }}$ birthday as an alternate cause for celebration:
} 
used in the major research paper: fifteen references to campaign material and forty-six references to participant responses. (Refer to object of study lists in Appendix.)

On location, face-to-face interviews afforded Mackey (2002) the further advantage of knowing something definitive about the subjects in terms of social and geographic location. In my analysis of the "Seven Wonders of Canada" campaign, the identity of the participants is not obvious. Occasionally, he/she reveals gender or what part of the country he/she resides in. They do not tell us who they are and how they belong to the nation except in small measure from the clues imbedded in their commentary. The inability to interview poses a disadvantage in that I am not able to ask questions that I may deem relevant or to exact clarification on a particular point. The campaign participants did not ask to be part of my research and their intended meanings may differ greatly from my interpreted ones.

\section{The literature}

The "Seven Wonders of Canada" campaign provides an excellent opportunity to explore and analyze the workings of a current, actual project of national identity. I borrow from the work of many in this analysis but I especially acknowledge Brian Osborne's (2001) notion of the importance of place in creating an "awareness of belonging", Eva Mackey's (2002) discussion on the power of "Canadian-Canadians" to include, exclude and position themselves and the Other and Ghassan Hage's (1998) analysis of nationalist multiculturalism in terms of accessing/controlling national space. The literature listed in the bibliography is used to analyze the campaign and response materials. Of the few articles located online; one is a government sponsored research paper, two are papers attached to universities and the balance are written by 
academic, published authors. Shani Mootoo's work of fiction is referenced because she offers such pertinent insight into issues of national belonging. Special comment is made about the books by Neil Bissoondath and Richard Gwyn which I reference in the paper. It is acknowledged that they are popular authors; that they have much to say that is relevant, generally, and to this paper, specifically, is supported by the fact that they are quoted by several of the academic authors referenced throughout my paper. Richard Gwyn in particular is not just quoted as a populist voice; his ideas are drawn upon by these authors in the furthering of their analyses.

\section{Theoretical considerations}

Campaign participants and the authors I am reading "know" from particular vantage points. As argued by Stuart Hall (1993), "we all write and speak from a particular place and time, from a history and a culture which is specific. What we say is always 'in context', positioned'. It follows that my interpretation of data and the literature in constructing the narrative of this major research paper is the result of my place in the abyss of power-balanced and imbalanced sociocultural interconnections and relationships that comprise this point in history. Dorothy Smith argues that the researcher's personal experience does not compromise objectivity nor contaminate knowledge; it represents a "point of entry" (as cited in Brooks, 2002, p.1). I continue with a statement about my "point of entry". I was born in the United States and have lived in Toronto as an American citizen for most of my adult life; just recently becoming a Canadian citizen, I now possess dual citizenship. I possess a profound attachment to both countries and in many ideological and practical ways think of myself as more Canadian than American. Because I am white and speak English, national belonging in Canada is presumed. I also acknowledge that my educational and professional background is in the field of social work 
and I strongly endorse notions of equity, respect and social inclusion. The theoretical framework in my major research paper borrows from Hage (1998) who discusses the relationship between race/ethnicity and territory. I research, analyze and write within an anti-racist theoretical framework but agree with Hage (1998) that nationalisms incorporate a "motivating ideology" (p.32). Racist modes of thinking are played out in the lived space of nationalisms where the exclusionary practices of the cultural centre determine who most rightly belongs in what space. While it is my intent to discuss the topic as objectively as possible, who I am is of necessity a part of the final product. 


\section{A review of the literature}

The purpose of the following review of the literature is to provide the reader with a sense of the socio-cultural backdrop against which the campaign unfolded and a review of the existing theory on Canadian national identity from which my analysis will draw. If nationalist activity has, historically, been a mainstay in Canada's attempt to define itself, it is also true that these activities are modified to suit the agenda of the current period (Osborne, 2001). If Canada's current socio-political posturing requires the public assertion of equity in the context of cultural pluralism, nationalist activity must move from overt to covert. Because regionalism and Canada's relationship with the United States proved to be prominent nationalist tropes in the "Seven Wonders of Canada" campaign, they are included in the discussion on Canadian national identity. Other Canadian nationalisms are more pertinent to the topic of cultural pluralism and my argument that the inclusion/exclusion paradigm inherent in Canadian nationalisms is amply evident in the "Seven Wonders of Canada" campaign. These are divided chronologically into two parts: a white nationalism centring on geography which overtly placed British-Canadians at the top of a racialized hierarchy (Berger, 1997) and a multicultural nationalism which covertly keeps White in the cultural centre (Hage, 1998; Mackey, 2002). While much is different in these early and late nationalisms, both reveal the intent of preserving a cultural order and both are reflected in the "Seven Wonders of Canada" campaign. The review of the literature begins with a general discussion on nation, the boundary between self and Other, nationalisms and contested identities. 


\section{Nation, boundary, nationalisms and contestation}

The nation-state "has been granted universal recognition and validity as the authorized marker of the particular" (Ang and Stratton as cited in Mackey, 2002, p.4). Also widely held is the position asserted by Zygmunt Bauman (1992), Ian Angus (1997) and Will Kymlicka (2000) that a conclusive definition of nation is untenable, that any list of requisite criteria would be equaled in number by exceptions. As a point of departure and borrowing from Max Weber's conceptualization of nation as a "community of sentiment", Kymlicka (2000) argues that communities qualify as nations when they view themselves as such. Benedict Anderson (1991) describes political communities as imagined; members, who for the most part are unknown to each other, share a communion. He argues that the notion of community typified by horizontal connection to fellow man rather than vertical connection to God/monarch became viable at the advent of modern thinking. Requisite to this development, he argues, was a move away from these previously accepted cultural concepts: that sacred script-language offered access to ontological truth, that society was naturally organized hierarchically and that cosmology and history shared an indistinguishable temporality. He further argues that the spatial/temporal aspects of print-language were crucial to the evolution of national consciousness, allowing for a sense of continuity over time and of immediacy despite geographic separation. If the advent of print-language represents a means of generating national consciousness, Osborne (2001) argues the equal importance of geography and landscape as conduits for cultural meaning and markers of shared, national identity. Osborne (2001) argues that particularly emotive aspects of place/geography are utilized to introduce/reinforce values; these landmark-meanings resonate and become part of the national narrative and "establish spatial and temporal reference points for society" (p.3). 
With this sense of shared sentiment developed a concomitant sense of finiteness, of boundary (Angus, 1997; Bauman, 1992). Bauman (1992) argues that a pre-modern worldview embraced many divisions and subdivisions but that modern thought was responsible for the alldefining division between civilized and uncivilized, One and Other. This dichotomizing result is further articulated by Bonilla-Silva (2000) who argues that modern European nations created a "structure of knowledge-meaning" (p.191) which separated notions of West from the racialized rest of the world. Eduardo Bonilla-Silva (2000) borrows from Andrew Markus in articulating this separation in terms of binary oppositions: human/subhuman, developed/underdeveloped, civilized/barbarian, rational/instinctive, Christian/heathen, superior/inferior and clean/unclean (pp.191-192). Migration patterns in recent history have rendered cultural pluralism within national borders a reality in most Western societies (Kymlicka, 2000). The historical legacy of the above-noted binary oppositions, then, plays out both at the geographic boundary of nationstate with respect to immigration policy and, as argued by Osborne (2001), within the space of nation in the form of contested boundaries between self and Other. Hage's (1998) analysis of multiculturalism in Australia adds much to the notion of binary oppositions insofar as he demonstrates they are not so binary. Social position in fact is a matter of degree along a continuum. Hage (1998) argues that Whiteness is an ideal; the bearer of Whiteness possesses "national capital". One can acquire "national capital" in terms of language, length of residence and acculturation and depending on the amount acquired, belong to the nation accordingly.

If shared sentiment and particular commonalities are the initial bonds constituting nation, nationalisms serve to legitimize the nation-state by encouraging boundary and a sense of 
inclusion/exclusion. Osborne (2001), Mackey (2002) and Daniel Francis (1997) argue that modern states could not persist as viable entities without an adequate body of symbol and myth to bind people to the state. Bauman (1992) asserts that nationalist movements do not uncover true nature and meanings; national identities are constructed. Nations do not inherently possess a particular identity or destiny (Bauman, 1992; Anderson, 1991; Osborne, 2001; Hall, 1993). Further, national identity is constructed within the context of power as a means to a political end (Angus, 1997; Bauman, 1992; Hall, 1993; Bhabha, 1994; Francis, 1997; Mukherjee, 1996; Bannerji, 2000), incorporating the notion of Other in opposition to the dominant subject - the One. In this view, the One constructs national identity to preserve his/her position of cultural centricity - while proscribing who belongs to the nation and who doesn't. Mackey (2002) argues that internal differentiation and cultural diversity are managed - whether through assimilation, institutionalization, appropriation or erasure - in the service of supporting the core national culture. "Categories of privilege" construct national identity in an attempt to maintain their status as elite, their position natural (Coleman, 2006, p.10).

Bauman (1992) asserts that the notion of shared attributes which integrate people into a spatial/temporal unity is illusory, that resultant boundaries are always contested. Assimilation is not one-directional; in the process of immigration/settlement neither majority nor minority remains unchanged (Alba 1999). Hall (1993) argues that the formation of cultural identity represents a positioning, not an essence - creating a politics of identity with hybridity as the result (p.402). Homi Bhabha (1990) identifies a "contested conceptual territory of double-time" (p.297) where the people of a nation function both as objects of nationalist pedagogy and as subjects in the present where renewable identity is negotiated. As asserted by Mackey (2000), 
Bhabha identifies a "third space of enunciation" (p.83) where cultural hybridity encourages antinationalist activity.

\section{Perspectives on Canadian national identity}

Mackey (2002) comments on reaction to her research from British and American colleagues who observed that issues related to Canadian national identity "seemed so constant, wide-ranging and anxiety-ridden" (p.8). Unlike an American national identity born of revolution, ideology and concomitant sense of empowered destiny, Canadian national identity has no such genesis (Francis, 1997). Chris Lorenz (2001) argues that any genesis of the Canadian nation is contested insofar as the very existence of $\underline{a}$ Canadian nation itself, rather than Canadian nations, is also contested. Nationalist tropes abound in the "Seven Wonders of Canada" campaign. Most prominent were the attachments to anti-Americanism and regionalism as demonstrated in participant voting and commentary. Less obvious but crucial to my argument are participant and judge attachments to geography as marker of identity that keeps White at the cultural centre.

Particular circumstances have posed challenges to the construction of a Canadian national identity: the conquest of indigenous peoples, a prolonged evolution from British colony to Canadian nation, waves of immigration from around the globe and a strong, influential neighbour to the south (Angus, 1997; Gwyn, 1995). Efforts to secure a cohesive national identity have been further jeopardized by the geo-politics of a large, sparsely populated territory in which a Federalist form of government fails to equalize power and economic disparities (Kaplan, 1994). Angus (1997) argues that Canadian national identity has encompassed a notion of

"fatality"; as a colony of France, Britain and the United States, Canada has a history of 
dependence on decisions and demands from elsewhere. Gwyn (1995) concurs, asserting that these longstanding international attachments of dependency, coupled with an unresolved history that centres on two founding fathers makes Canadian national identity especially vulnerable. Asserting that Americans know or think they know what it is to be American, Gwyn (1995) argues that the closest Canada comes to having a national creed is a vague articulation of reformist liberalism and a broad-based acceptance of the ideals of cultural pluralism and tolerance. Angus (1997) argues that notions of national identity, earlier defined by state promoted social goals and currently defined by multiculturalism's ideology of difference, reflect a basic structural adjustment in which centripetal/toward the centre has been replaced by centrifugal/away from the centre. Janine Brodie (2002) argues that the "Social Canadian" comprises the cultural centre, a national myth "largely representing the aspirations of EnglishCanada" (p.386).

Gwyn (1995) argues that within the bonding structures of interdependent economies, Canadians are "a la carte" Americans; Canadians opt into American culture, protest against American foreign policy and articulate the nationalist urge to be different from Americans. David Kaplan (1994) argues that it is difficult for Canada to assert a strong national identity insofar as, historically it has defined itself in great part by what it is not: British or American. If national identity is constructed in part in terms of negation, the United States has served well as Canada's "identity ex negativo" (Lorenz, 2001, p.5). A constant trope of Canadian national identity throughout the country's history, this "negative bond", Lorenz argues, is the result of a proximal/imminent sense of threat - that the United States may usurp land, resources and/or culture. When immigration was deemed an essential strategy to populate Western Canada as a 
protective measure against American imperialism (Berger, 1997; Kelley \& Trebilcock, 2000), promotional activities included assertions of Canada as a cultural mosaic, with its purported notions of valued, power-neutral difference among races and cultures - constructing cultural pluralism as a national identity which was interesting and different from that of the United States (Francis, 1997). In this view, immigration policy represents strategy; the immigrant as object is used by the "Canadian" as subject to promote and protect national sovereignty. Shields (1991) argues that the "True North" space-myth functions as an anti-continentalist nationalism, allowing for difference between the United States and Canada however much cultures conflate. Erin Manning (2000) argues that anti-American nationalisms encourage a monolithic notion of Canada which obscures notions of diversity and difference.

As argued by Gwyn (1995), Canada's version of federalism, pushed to an extreme related to Quebec's separatist ideology, makes it one of the most decentralized countries in the world. Regionalism complicates identity attachment for those immigrants negotiating a balance between ethnic community and nation. In the case of Quebec, albeit an extreme case given the province's strongly asserted sub-nationalisms, Danielle Juteau (2002) argues that immigrants relate more to Canada as nation than Quebec as nation within a nation. Included in the space of Quebec, yet distanced from historical meanings of separatist politics, immigrants are attempting to belong in Canada; by the Quebecois they are valued as presumed supporters of separatist politics. As argued by Andrew Nurse (2002), the construction of regional identities involves coding that delineates inclusion/exclusion of other identity markers (p.17). By way of demonstration, he references a study of a predominantly white Maritime community where multicultural ideals had no place in that community's sense of what it means to be Canadian (p.18). 
Mackey (2002) argues that if the longstanding efforts of British-Canadians to maintain their position of power at the cultural centre were to be successful, cultural pluralism has had to be managed from the outset. The Royal Proclamation of 1763, the Quebec Act of 1774 and the Immigration Act of 1869 can be seen to mark the beginnings of the management by the dominant culture of indigenous peoples, French Canadians and immigrants in shared Canadian space (Mackey, 2002, p.23). Mackey (2002) argues that the Royal Proclamation of 1763 supported aboriginal rights to western land in large measure as strategy to encourage protestant immigration of American colonists to Catholic Quebec. When this migration failed to materialize and with pre-Revolution discontent in what would soon become the United States, "presentist agenda" Osborne's (2001) took the form of the Quebec Act of 1774 which offered protection to Quebec - this time viewing the threat as imperialism from without rather than diversion within.

These strategies represent cultural management designed to protect the cultural centre (Mackey, 2002, p.27) and demonstrate that the construction of national identity supports hierarchical, racialized power structures which proscribe inclusion/exclusion (Mackey, 2002; Osborne, 2006). These nationalisms have evolved from more to less overtly racist throughout Canadian history to the extent that current notions of cultural domination take the generally unspoken form of normative (Mackey, 2002; Bannerji, 2000). To date, White remains centrally located but not without ongoing rights-based negotiations in socio-political space occupied by cultural groups and characterized by notions of cultural hybridity. These contestations have unfolded in the literal and figurative spaces of Canada, taking meaning from and giving meaning to its geography. Manning (2000) argues that it has been the connection between territory and identity that has enabled Canada to envision itself as a nation. As noted by Shields (1991) and 
John Burrows (2001) language follows concept; when one speaks of an event "taking place", inferred is the sense that event impacts geography, imprinting particular meanings. Canadian national identity has been constructed throughout history with particular meanings attached to geography to provide justification, delineate boundary and ascribe belonging. With its requisite attention to cultural pluralism, these ascribed meanings have done much to include, exclude and position - to determine centre and periphery.

Meanings attached to place have been revised over time as dictated by current agenda (Berger, 1997; Mackey, 2000/ 2002; Osborne, 2001; Manning, 2000). Early assertions of the manifest right of the British to Canadian land have been reworked to include currently contested notions of geography in terms of where the "real" Canada is located (Mackey, 2002; Peake and Ray, 2001). Overt has become covert but it is the same cultural centre that asserts control over literal and figurative space. In this view, geography becomes problematic with respect to who has the power to transform it into social and psychic space and who is powerless against exclusion from these representations (Manning, 2000; Mackey, 2002; Razack, 2002). If Mackey (2000/2002), Manning (2000), Osborne (2006), Sherene Razack (2002) and Linda Peake and Brian Ray (2001) are troubled by power imbalances evident in current identity politics, others are less so. Gwyn (1995) and Charles Taylor (1992; 1993) attach themselves to historic sensibilities, albeit ones that are contested in much of the literature to be racist, which centre on the British as inheritors of Canadian territory and as rightfully located in the cultural centre. 


\section{White geography}

The 1868 nationalist Canada First Movement, in which North is the psychic space of national identity, was one answer to founding member Robert Grant Haliburton's question, "Can the generous flame of national spirit be kindled and blaze in the icy bosom of the frozen north?" (Berger, 1997, p.5). Daniel Francis (1997) argues that North, the subject matter of many of the paintings of the Group of Seven, was an idea, a myth that represented both a promise and destiny unique to British-Canada. Integral to these early nationalisms was a theory of environmental relativism asserted as follows: the challenge to survive Canada's northern climate was best suited to people from Britain and other northern European countries and that from this struggle a self-reliant, intelligent, brave people would emerge (Francis, 1997; Berger, 1997). Already self-located at the top of the evolutionary scale, British-Canadian civility, with its concomitant valuation of will, science, progress, and liberty, could only be improved upon in the context of Canadian geography (Berger, 1997; Coleman, 2006). So strong was the sense of British-Canadian as the ideal, national identity was articulated in terms of a "northern race" (Berger, 1997; Francis, 1997; Mackey, 2000).

Despite a firmly rooted presence in the very same northern geography, indigenous peoples are not considered to be part of Francis' (1997) paradigm of North, in which geography encourages bravery, intelligence and self-reliance. As noted by James Henderson (2002), "federal law denied that Indians were "persons" until 1951; in this view indigenous peoples could not be part of British-Canada's civilizing project. Kaplan (1994) references Burghardt and Sack in arguing that spatial identity represents a movement from neutral occupation of territory to an awareness of the territory's intrinsic meaning to the occupiers. White-settler representations of Canadian geography reflect the social relations of domination, providing justification for 
projects of colonization and conquest. The concept of terra nullius, as part of the "civilizing" project of progress, prescribed inhabited geographic space as "uninhabited", thus enabling the "civilized" British to justify the excision of "uncivilized" indigenous peoples from desired land (Razack, 2002).

This supposed right to the land, juxtaposed against Burrows' (2000) description of indigenous citizenship as a codified, harmonious relationship with this very same land, begins to expose the disconnect in early Canadian-Aboriginal relations. These relations, never powerneutral, reflect a paradigm in which the value attached to indigenous peoples was historically managed and modified by the British-Canadian cultural centre to maintain its centricity. Even while lands were appropriated and cultures decimated, the cultural centre promoted notions of Canada as possessing traits of British civility and concomitant kindly treatment of indigenous peoples - thereby attempting to establish a cultural trait differentiating Canada from the United States (Mackey, 2002; Francis, 1997) and differentiating British-Canada from other cultures within Canada. The cultural centre has historically attached meaning to the French-Canadian peoples in the promulgation of British-Canadian nationalisms. The French were deemed to be a people of the North thereby making them part of the same nationalist group as BritishCanadians; yet, they were simultaneously used to demonstrate that Canada possessed a cultural pluralism not found in the United States (Mackey, 2002).

In the context of early nationalisms which attached identity to geography, it was BritishCanadians who ascribed meaning to geography and proscribed the parameters of belonging to the nation. As argued by Mackey (2000), immigration policy marks the intersection of the material needs of state and the cultural needs of nation; nationalist discourse does not favour 
immigration except in economic and assimilationist terms. At the turn of the twentieth century, nation building created a demand for labour that could not be met locally or from traditional, preferred counties of emigration, thereby straining the relationship between "white" national identity and nation building. The Chinese, initially valued as a source of cheap labour, were completely devalued as the construction of the Canadian Pacific Railway reached completion, as evidenced by the implementation of the Chinese Immigration Act of 1885 which imposed a head tax on men and denied entry to women and children (Jackubowski, 1997). When tens of thousands of non-British Europeans arrived during each of the years just before and after the turn of the twentieth century, "white/British" national identity was "threatened" by central and Eastern European immigrants; Ninette Kelley and Michael Trebilcock (2000) reference the Winnipeg Telegram which, in 1899, offered sympathy to the British-Canadian who found himself "hemmed in by a hoard of people little better than savages - alien in race, language and religion, whose customs are repellent and whose morals he abhors" (p.131).

Geography with its ascribed meanings for white superiority is explicitly expressed in the immigration policy of the period. In her analysis of "White Canada" policy; Lisa-Marie Jackubowski (1997) references section 38[c] of the Immigration Act of 1910 which outlines that entry could be denied to:

Any nationality or race of immigrants of any specified class or occupation, by reason of any economic, industrial or other condition temporarily existing in Canada or because such immigrants are deemed unsuitable having regard to the climatic, industrial, social, educational, labour ... or because such immigrants are deemed undesirable owing to their peculiar customs, habits, modes of life, methods of holding property and because of their probable inability to become readily assimilated or to assume the duties and responsibilities of Canadian citizenship within a reasonable time after their entry. (p.16) 
The 1910 Act included policy which encouraged immigration from the United States, the British Isles, France, Belgium, Holland, Switzerland, Germany; Denmark, Norway, Sweden, and Iceland (Jackubowski, 1977) paralleling purported Northern aspects of Canadian national identity. "Undesirable" countries were unspecified and left to immigration official discretion. It wasn't until the Immigration Act of 1952 that the Chinese Immigration Act of 1885 was repealed; the 1952 Act still embraced the concept of "most easily assimilated" immigrants from British subjects from around the world and citizens of the United States.

Immigration policy can be seen to reflect socio-cultural notions of national identity in Prime Minister Mackenzie King's 1947 Statement on Immigration. ... “[The] people of Canada do not wish, as a result of mass immigration, to make a fundamental alteration in the character of our population". Ambivalence toward immigrants in the context of nation building was clear: valued for the contribution of labour and devalued for the perceived threat to national identity (Mackey, 2002; Kelley and Trebilcock, 2000). If immigration policy delineated that a prospective immigrant's inferior ability to manage the climate was reason for denial or qualified entry, it was Canada's northern geography that naturalized this racialization (Mackey, 2002; Berger, 1997; Osborne, 2006) insofar as both Canada's geography and ascribed character traits were deemed beyond anyone's control. As asserted by Mackenzie King in referencing immigration policy:

... not because of any declaration of individual or national superiority on the part of the people of Canada over the people of any other nation, country or race ... The country is the people and the people are the country. (cited in Kelley and Trebilcock, 2000 p.163) 
Geography, thusly, concurrently in nationalisms and immigration policy, was the conduit for notions of inclusion, exclusion and positioning (Mackey, 2002). The geography of Canada became an agent of power, naturalizing a social construction which placed British-Canadians and those easily assimilated at the centre (Osborne, 2001; Mackey, 2000) and in possession of a spatial identity which encompassed the entire Canadian state (Kaplan, 1994). Geography, as a cultural medium, resembles ideology insofar as it naturalized constructed meanings, making them appear given and inevitable (Osborne, 2001). In attaching character traits to latitude, geography, as symbol and signifier of identity, "patriotic topography" (Daniels in Osborne, 2001) has different meanings for different cultures - evident both in the early years of nation building and in the "Seven Wonders of Canada" campaign.

\section{Nationalist multiculturalism}

The Multiculturalism Act of 1985 legislated equality in the context of cultural pluralism both in terms of heritage and opportunity. For a number or reasons, not the least of which being Canada's signing of the UN Charter in 1944, immigration policy, while still demonstrating a propensity to balance national identity as English-Canadian with the material need for labour, was evolving into something less racist (Kelley and Trebilcock, 2000). By 1967 overtly racist language had been removed from immigration regulations; the point system, which credits immigrants for particular educational/experiential credentials, however, still tended to favour immigrants from particular countries (Kelley and Trebilcock, 2000). By the 1980's "untraditional" source countries had become the norm; approximately 48 per cent of immigrants coming to Canada between 1981 and 1991 were from Asia and the Middle East (Kelley and Trebilcock, 2000). Multiculturalism, a policy defined in official government ideology as "a 
fundamental characteristic of Canadian heritage and identity" (Mackey, 2002), represents a distortion of history. While Canada has always been culturally plural, its public valuation of the pluralities has been inconsistent. Congruent with "presentist agenda" (Osborne, 2001), multiculturalism promotes a nationalist notion of Canada's tolerance toward its multi-cultures, yet is argued by many to maintain English-Canadians in the cultural centre by its naming and positioning of immigrants/visible minorities (Mukherjee, 1996; Bannerji, 2000).

The reality of cultural pluralism in Canada is understood in some manner by all critics; Daiva Stasiulis (2002) argues that the rhetoric of multiculturalism is belied by the experiences of minority groups (p.365). Pierre Coulombe (2000) delineates demographics as they impact upon the major players on the national stage. Neither the French nor the English can currently claim to represent more than twenty-five per cent of the country's population (Coulombe, 2000, p.282). Mackey (2002) argues that this very threat to the cultural centricity of English-Canadians has elicited reaction in terms of increasingly forceful rhetoric to reinforce the centre's longstanding ability to manage cultural difference to its advantage. English-Canadian cultural centricity, still viable despite demographics that augur for an alternate distribution of power, is contested by many minority groups. Current literature reveals the many issues, obvious and nuanced, pertinent to multiculturalism and so, too, to my analysis of the "Seven Wonders of Canada" campaign.

Any discussion of cultural pluralism in Canada of necessity includes indigenous peoples. It is both the imposed marginalization of indigenous peoples and self-declared right to Nation that has made inclusion of indigenous peoples in the multicultural paradigm impossible in the usual sense. The political marginalization of indigenous peoples, in terms of who has power and 
authority to interpret law and determine civil rights, has remained constant, recent inclusion in constitutional debate notwithstanding (Bannerji, 2000). Current notions of treaty, reservation, band, Aboriginal control of Aboriginal affairs with concomitant marginalization serve to exemplify. Mackey's (2002) notion that authority continues to rest with the English-Canadian cultural centre. Reflected in the Aboriginal debate on Canadian-Aboriginal relations is the notion of power imbalance and contestation that takes two forms: integration with a view to representation and equalization of power and self imposed segregation with a demand for recognition and power. Burrows (2000) calls for continued control of treaty acquired land; embracing modern and post modern notions of cultural hybridity, he seeks integration and Aboriginal influence, if not control, over Canadian affairs. Henderson (2002) rejects federal citizenship, arguing that the invitation from the Canadian government disrespects sui generis Aboriginal rights and offers more of the same: colonialism and cultural domination.

The discussion on multiculturalism, instead, consistently, begins with the French who also demonstrate a self-declared right to Nation but who, in contrast to indigenous peoples, are largely included in any national project. In this view Quebec sees itself as outside of the multicultural paradigm; the rest of Canada views it as included. Francis (1997) concurs with Ramsay Cook's assertion that "the Conquest is the burden of Canadian history" (p.91), identifying the Conquest as a definitive point of departure for the notion of "two solitudes" in Canadian identity politics. He argues that each side has attached different meanings to the event; a Quebecois je me souviens remembering with its current call for some degree of sovereignty being very different from an English-Canadian interpretation of victory as rescue of the people of Quebec from French feudalism. Since the Conquest, English-French relations have centred on 
English accommodation/French assertion of cultural distinctness and political influence - at times critically and with threat to the unity of the country (Angus, 1997; Gwyn, 1995; Mackey, 2002; Francis, 1997). Attachment to the Catholic Church as primary locus allowed an early French-Canadian spatial identity that was both local and continental; insofar as the "Quiet Revolution" signaled a power-base move from religion to politics, Quebecois ethno-national identity connects itself to the territory of Quebec (Kaplan, 2004). Despite a shift from culture to territory as the primary basis of community parameters, the Quebec state continues to push for a homogenized notion of identity and belonging (Juteau, 2002). Attachment to territory allows Quebec to assert itself as a nation within a nation, complicating identity attachments for English people in Quebec and French people in the rest of Canada.

Himani Bannerji (2000) and Mackey (2002) among many others are critical of multiculturalism, arguing that it serves to maintain a precarious relationship between cultures in which power imbalance is calculatingly perpetrated. Bannerji (2000) argues that if historic English-French relations and appropriation of indigenous land/culture represent the foundation of Canadian nationhood, they, too, provide the modus operandi for later dealings with the immigrant Other. Multiculturalism's formal discourse with its rhetoric of "democratic" and "equal treatment" obscures practical meanings of race and class. Class distinction becomes readily evident when consideration is given to the notion that the White cultural centre is not one of the multi-cultures generally included in practical meanings of multiculturalism. In a Marxist analysis, the multi- cultures represent a class controlled by the cultural centre. The multi-cultures are viewed as a commodity and valued/exploited for their contributions in terms of labour and culture (as entertainment). The very centricity of the White centre is not questioned, just as the 
interests of Marx's capitalists are taken as a given. It is the intersection with race, or more to the point Hage's (1998) "national capital", that gives viability to the class distinction. It is the absence of "national capital" that provides visibility; while education, language/accent are factors, Hage (1998) especially argues that it is "Third World-looking" people who remain in the "spatial in-between where their will is excluded" (p.137).

Brodie (2002) borrows from Gwyn's notion of Canada as a state-nation, arguing that the notion of Canada as state came first, with subsequent attention to creating a sense of nation which has consistently aimed to contain sub-national and ethnic conflicts. Multiculturalism as policy was not implemented out of beneficence toward the "other" but rather as strategy to keep "other" groups in a position subordinate to the English-Canadian centre (Bannerji, 2000; Mackey, 2002). Ethnic populations were appeased when bilingualism/biculturalism was reformulated to include the multicultural context in which state supported cultural maintenance programming, but not political power, was accessible (Mackey, 2002; Bannerji, 2000; Coulombe, 2000). Immigrants, as essence, and "visible minorities", as tangible, counter French difference (Bannerji, 2000). The French claim to a theoretical half interest in the national project with respect to $b i$-lingualism/ $b i$-culturalism is thwarted by the cultural transcendence of multiculturalism (Bannerji, 2000, p.94), thereby, as argued by Mackey (2002), minimizing "Quebec's more threatening difference" (p.64). In this analysis minorities are strategically kept "visible" (Bannerji, 2000). In promoting cultural retention, multiculturalism has the potential to encourage a stifling notion of immigrant identity - a looking back rather than forward, or inward rather than outward (Gwyn, 1995; Bissoondath, 1994; Lopicic, 2002). So, however positively 
"diversity" is addressed in multicultural policy, "difference", with its vestigial attachment to meanings inherent in colonialism, is not power neutral (Mackey, 2002; Bannerji, 2000).

Bannerji (2000) is critical of the very naturalness of the arrangement, espoused by Taylor (1993), in which there are levels of diversity and different ways of belonging to Canada, that the English belong in a manner different from the French and indigenous peoples and that these three groups in turn belong in a manner still different from groups possessing "mosaic identity". Bannerji (2000) contests Taylor's assertion that it is English/French Canadian culture that is central and the standard against which the contributions of other cultures must be measured. Taylor (1993) argues:

It makes sense to demand as a matter of right that we approach the study of certain cultures with a presumption of their value .... But it can't make sense to demand as a matter of right that we come up with a final concluding judgment that their value is great, or equal to others. (p.69)

To accept cultural contributions of the Other at face value in Taylor's (1993) view is condescending; these contributions, he argues, must be evaluated by mainstream culture. In this point, Bannerji (2000) is correct to challenge Taylor's notion that "we" are the judges. No doubt his "we" includes immigrants possessing requisite "national capital", a certain ethnic hybridity; however, it is rife with class distinction. Gwyn (1995) and Angus (1997) take a similar view to Taylor (1993), arguing that English-Canadian national identity is the basis of Canadian national identity and that Canada is in danger of losing its centre if English-Canada allows itself to become one of the multi-cultures. This kind of national identity discourse "depends on the investment in a historical trajectory that silences the implicit link between colonization and 
imperialism in Canada" (Manning, 2000, para.30) and finds ample representation in the "Seven Wonders of Canada" campaign.

Kymlicka (2000) argues that the convergence of liberalism and cultural pluralism necessitates a sociopolitical theory which respects "both the claims of ethno-cultural minorities and the promotion of responsible democratic citizenship". Integral to any such theory is the negotiation of the individual-based principles of liberal democracy with the rights of minority ethno-cultural groups. Yasmeen Abu-Laban (2002) argues that it is at this point that multiculturalism gets into difficulty. Acknowledging the importance of "strategic essentialism" (p.461) as emancipatory, it is the commonsense brand of essentialism in which each culture has an externally determined fixed essence that is the problematic. Purportedly neutral "difference blind" rules create privilege for the normative group and disadvantage for minority groups, whose identity and interests are thereby placed in jeopardy (Kymlicka, 2000; Taylor,1992; Bannerji, 2000). A laissez-faire approach to equity unfairly favours the majority, while special efforts on behalf of minority groups are deemed as unfairly preferential. Acknowledging that minority rights claims have resulted in differentiated citizenship, Kymlicka (2000) argues for "reasonableness", centring on public debate which would evaluate the public value of political demands. Kymlicka (2004) argues that this notion of "public", with its requisite tension between diversity and unity, is dynamic and that earlier notions of national identity change as national circumstances change. In this view responsible democratic citizenship is key; if the multicultures practice civic participation, equalization of power will be the eventual outcome. In stark contrast to Taylor's (1992) notion of where cultural power rests and in his view rightly rests, Kymlicka's (2004) notion of equalization of power, however, is not yet reality. 
Bannerji (2000) and Mackey (2002) argue that this tension between diversity and unity is riddled with power imbalances which are further perpetuated by the policies and ideology of multiculturalism. Multiculturalism as policy contributes to a sense of Canadian national identity as tolerant of cultural pluralism, while at the same time maintaining the sense of a normative centre against which the cultural/ethnic Other is different. In the Australian context Hage (1998) holds a similar view to this and agrees with Kymlicka that the current demographics of cultural pluralism are such that multi-cultures are effecting a real impact on cultural politics. Hage (1998) argues that the racialized reaction from the cultural centre has more to do with nationalism than racism insofar as the negotiation/contestation is unfolding within the space of nation. In this view, racism remains secondary; nationalism explains the cultural centre's attempt to maintain its authority in the lived-in space of nation where multi-cultures pose a threat to normative. Mackey (2002) and Peake and Ray (2001) argue that it is small town Canada which asserts the notion of being the "real" Canada. It is there that "Canadian-Canadians" (Mackey, 2002) assert the brand of nationalism in which state-sponsored multiculturalism is challenged. Acknowledging the rhetoric of value, respect and inclusion in multiculturalism as policy, Razack (2002) argues that cultural pluralism has imparted particular meanings to current day geography. The historic ideology of geography as empty wilderness available to white settlers becomes current-day ideology of geography as space besieged by Third World refugees and migrants attracted to the Canadian ideals of democracy and orderliness (Razack, 2002).

What becomes clear in this review of the literature is the position of power from which cultural and sub-national groups are included, excluded and positioned in the construction of 
national identity. It is this very ideology of Whiteness, with its notions of the normative power of Gwyn's (1995) English-Canadians and Mackey's (2002) Canadian-Canadians to establish the parameters of national identity and belonging and to perpetuate these notions of superiority/control in a covert, often indiscernible manner. It is in this cultural milieu of national identity promulgation and contestation that the "Seven Wonders of Canada" campaign was undertaken. The balance of my major research paper will analyze the campaign drawing from the themes and issues raised in this review of the literature. The relationship between geography and national identity, with vestigial attachment to the colonizing project and a "white" Canada, establishes a starting point to my analysis insofar as geography represented much of what was determined to be "Canadian" in the "Seven Wonders of Canada" campaign. My analysis draws on the critique of multiculturalism contained in the literature review to further demonstrate that the $\mathrm{CBC}$ and the judges, while overtly suggesting notions of equitable representation in the campaign, are including but also positioning and excluding. 


\section{Research analysis}

If the goal of this major research paper is to demonstrate the exclusionary aspects in the "Seven Wonders of Canada" campaign, there are several ways that the story could be told. For purposes of clarity, I opt to structure the body of my major research paper so that it parallels the chronology of the campaign; any exception to this guiding principle is duly noted. In this way, each chapter of the campaign lends itself to a thematic section in the paper. In each chapter of the campaign, promotional material from campaign organizers and quotes from the judges (located in the various pertinent "Seven Wonders of Canada" CBC official websites) and more often from the participants (located in various pertinent Seven Wonders of Canada official and personal blogsites) are analyzed. In attempting to base my interpretations on evidential clues, I argue that the $\mathrm{CBC}$, the "Seven Wonders of Canada" campaign and campaign participants represent a cultural centre, an essence of Whiteness that includes, positions and excludes. The evidence in support of my argument builds throughout the paper; it is the material in the blogsites in reaction to the judges' list of seven at the end of the campaign process that is most revealing.

This part of the paper firstly addresses aspects of inclusion/exclusion attached to the $\mathrm{CBC}$ itself and the "Seven Wonders of Canada" campaign, in terms of who is overtly/covertly "invited" to participate. The balance of the paper is divided into three main sections. In "White geography", the conflation of geography and national identity is demonstrated in the nominating/voting by the participants; the manner in which this conflation includes/excludes is discussed. In the penultimate section, "multiculturalism" as nationalist trope is revealed in the final list created by the judges. Lastly, reaction to the final list reveals a sense of the campaign participants as "the people". 


\section{The CBC/the "Seven Wonders of Canada" campaign participant}

Ultimately, there are many readings of the Seven Wonders of Canada project, including the socio-culturally critical one which is the basis of this paper. I begin my argument - that the notion of national identity promulgated in The CBC's "Seven Wonders of Canada" campaign is exclusionary - with the $\mathrm{CBC}$ and the campaign participant.

In the spring of 2007, the CBC announced the "Seven Wonders of Canada" campaign and challenged viewers to submit nominations. I begin with consideration of what may be known about participants in the campaign - who felt they could submit nominations and venture opinions. The campaign participant is a person with enough cultural capital to speak English and to own/have use of both television and computer. The $\mathrm{CBC}$ resonates for the campaign participant; whether he/she agrees with everything the CBC produces; the $\mathrm{CBC}$ possesses credibility as the voice of their "Canada". He/she experiences a connection to certain programming and to the Canadian Broadcasting Company's notion of "Canadian" programming and "Canada". The campaign elicited strong, varied reaction. As TV critic for the Globe and Mail newspaper, John Doyle (campaign participant \#1) was a harsh critic of the project.

It's one thing to have a go at determining the greatest Canadian in our history. It's entirely base and brainless to engage in a gee-whiz competition to determine what CBC calls the "Essential Canadian-ness" of places. It's an act of tin-pot patriotism, better suited to a school essay competition than a national broadcaster.

At the other extreme, campaign participant $\# 2$ was effusive and positive.

A wonderful list - Canada is so beautiful and we are so lucky!

When the short list came out, I went from one to the other saying 'I like this one better.' 
In determining why particular people, such as the two participants referenced above, choose to participate, I borrow from Hage's (1998) analysis in which mode of national belonging is key. He articulates the difference between "passive belonging" as in "I belong to the nation" and "governmental belonging" as in "This is my nation" (p.45). It is the domain of Hage's (1998) "governmental belonging" in which the bearer believes that he has rights over the nation, to contribute to its management in such a manner that it remains 'one's home' (p.46). The person with "governmental belonging" possesses a position of privilege with the concomitant authority to offer "legitimate" opinions about the nation. As such they are the enactors of the national will (pp.46-47). Just as this "governmental belonging" can take the form of proscribing who belongs in national space, it, too, can proscribe who participates in a project of national identity. In this view, it is a person with "governmental belonging" who can criticize a project of national identity and proscribe the parameters of representation and belonging. It goes without saying that many people with "governmental belonging" would choose not to participant in the campaign. However, I argue that new immigrants, who have not yet acquired "national capital" in terms of language, familiarity, long-term residency (Hage, 1998, pp.53, 92) and who also do not possess a sense of "governmental belonging," are less likely to participate in and/or challenge the limiting parameters of the campaign.

Central to the topic of the paper is the campaign criterion calling for essential 'Canadianness'. The analysis begins with campaign participant \#3, who captures the intended essence of the campaign:

... it instills a sense of pride in one's country it honours monuments, institutions, natural wonders together as a nation it encourages dialogue ... Canadians [my emphasis] are coming together from all parts of Canada and, indeed, the world to talk and debate on the various nominees 
S

As will become clear in the following analysis, at least two meanings can be attached to the notion of "Canadians": all Canadians with inherent degrees of empowerment and representation or those Canadians from the cultural centre who think of themselves as the "real" Canadians. A campaign such as this could, in theory, "encourage dialogue"; however, impediments to this process become evident in the discussion that follows. Campaign participant \#4 states:

When I see commercials for these CBC shows, I sigh. Maybe some people like them, but I see them as lame attempts at national pride. I know I'm cynical, and I love this country as much as anyone, but I still don't care.

I rather prefer the shows that don't try so hard. I used to watch "On the Road Again", for example. The comedy skit shows like "The Rick Mercer Report" and "This Hour" do a good job at finding the pulse of Canadian culture [my emphasis].

It is crucial to consider who is included in and excluded from the particular "pulse of Canadian culture" captured in the "Seven Wonders of Canada" campaign. I look to the CBC to get a sense of this inclusion/exclusion paradigm: whose "Canadian-ness" is being promulgated within the framework of the campaign begins to reveal itself with respect to $\mathrm{CBC}$ attitudes affecting programming and viewer-ship. The $\mathrm{CBC}$ mandate addresses multicultural representation as outlined in the 1991 Broadcasting Act section 3 [d] [iii]:

the Canadian broadcasting system should ... through its programming ... serve the needs and interests and reflect the circumstances and aspirations, of Canadian men, women and children, including equal rights, the linguistic duality and multicultural and multiracial nature of Canadian society and the special place of aboriginal peoples within that society. (CBC Corporate Policies, p.1)

As per the Annual Report on the Operation of the Canadian Multiculturalism Act, CBC's

Corporate Research Department committed to use its annual Quality Research Survey (QRS) to determine use of and attitudes toward $\mathrm{CBC} /$ Radio Canada by ethnicity (CBC Annual Report, 
2002-2003). This report is not available to the public. With respect to the CBC's mandate to address what the campaign refers to as "an uneven population base" (campaign material \#vi) in the context of "the multicultural and multiracial nature of Canadian society" (CBC Corporate Policies, p.1), the need for such a report signals a problem or unresolved issue. It is clear that issues of fair representation in the context of state operated television for a culturally plural audience are given consideration; that this mandate for programming which reflects cultural diversity remains unmet is widely supported. Asserting that the " $\mathrm{CBC}$ culture" of homogeneity is pervasive and well documented, Guy Leshinski (1998) outlines a pattern of exclusionary hiring and programming practices.

It is clear that those responsible for the "Seven Wonders of Canada" campaign recognized that there would be a certain built-in bias in the popular vote, a vote which reflects the group of people who watch $\mathrm{CBC}$ and listen to Radio Canada. Included in the rules (see page 3 of Introduction for complete list) was allowance that there be "range within the final seven diversity of location, type of wonder. At the end of the contest when anger surfaced with respect to the judges' list differing so much from the popular vote, it became clear that this rule had been overlooked or ignored, despite its articulation at the outset. Campaign participant \#5 appears to have taken note of what many participants missed or chose to ignore at the end of the campaign:

You will note that factor \#5 gives the $\mathrm{CBC}$ the ability to diversify the pot. Should the results end with 7 wonders all located in the Atlantic region, for instance, undoubtedly, the final tabulation would be skewed to show diversity. Call it the affirmative action card.

The point is, then, that the very articulation of the rule demonstrates not only that the popular vote might not elicit the fair representation desired, but more fundamentally an awareness that 
the issue exists. An after the fact $\mathrm{CBC}$ apology included a statement reflecting an awareness of unequal representation:

We think [the judges] did an excellent job at meeting key criteria of this project, including creating a list that represents as many Canadians and regions as possible. It's why we felt we needed judges in the first place, to try and level the playing field in a country with an uneven population base, uneven internet access, and areas where a majority of Canadians don't listen or watch English radio or television and therefore wouldn't be able to participate. (campaign material \#vi)

If the campaign was relying on the judges to ensure fair representation, it is important to consider who the judges are and how they are described in the campaign literature. Ra McGuire, from British Columbia, is a member of the musical band, Trooper, and has written a book called, Here for a Good Time (Not a Long Time) - On the Road with Trooper. Roy MacGregor is a newspaper columnist and author, most recently of the book, Canadian. Roberta L. Jamieson is a lawyer with special interest in advocacy of indigenous rights, currently serving as the Chief Executive Officer of the National Aboriginal achievement Foundation (campaign material \#vii). Particular note is taken that the CBC description of the three judges named Ms. Jamieson as a Mohawk woman, while leaving the two white, male judges unnamed. With so much diversity to choose from, the campaign choice of an indigenous woman as judge is telling and may represent part of Mackey's (2002) argument that current state sponsored notions of national identity often suggest that indigenous peoples are not only Canadian but have always historically been so (pp.73-76). On the other hand, this notion of white male as normative and indigenous woman as Other reveals an alternative glimpse of what the $\mathrm{CBC}$ may view, unwittingly or otherwise, as "Canadian". 
Participants responded to the judges' assertions that the (regional) diversity of Canada would receive fair attention and representation when their final choices were being made. Campaign participant \#6's comment hints at factors, inherent in the notion of regionalism, which affect identity and geographic attachment:

like anyone else's choices, mine naturally reflect my own Southern Ontario and Northern biases. This is perhaps forgivable given our diversity, history and just how honking big our country is.

What becomes clear for many participants is that the notion of diversity relates to regionalism; other aspects of diversity and exclusion are not given consideration. The $\mathrm{CBC}$ mandate (see reference on page 34) addresses cultural diversity and the above-referenced campaign pronouncement (see reference on page 36) credits the judges with having created "a list that represents as many Canadians and regions as possible" (campaign material \#viii). In this statement, the reference to region confuses the meaning of Canadian: Canadians within regions or Canadians irrespective of region. However, there is no confusion in the comments of many campaign participants that for them the most meaningful difference amongst Canadians centres on region. Discussion on the exclusionary aspects of regionalism follows in "The final list: nationalist tropes and strategies" section of the paper when the choices of the judges are analyzed.

In the context of the "Seven Wonders of Canada" project, representation and participation are problematic. In asserting the $\mathrm{CBC}$ role as protector of Canadian culture, Gwyn (1995) argues that it is "the state or the States". In the CBC's notion of Canadian culture, 
exclusionary aspects of cultural homogeneity surface; diversity within Canada is obscured. Campaign participant $\# 7$ asserts,

$\ldots$ and who better than the $\mathrm{CBC}$ to sponsor such an event. The $\mathrm{CBC}$ is about the only thing that reaches just about every home and person in the country.

This suggests a notion of exclusion, that somehow "all" or "real" Canadians are included in any $\mathrm{CBC}$ project. There is a certain passivity to this statement suggesting Whiteness and the naturalness of this participant's way of belonging to nation; wittingly or otherwise, the participant is not acknowledging all those Canadians who in some manner are excluded. Authority was given to the judges based on a priori "governmental belonging" and taken by participants with this same sense of belonging and right to opinion. As argued by Mackey (2002), more important than whether minority groups are represented, positively or otherwise; is the issue of who decides how they are represented. Minority representation is important; however Mackey (2002) notes the historical propensity of the Canadian government to represent minorities to its own best advantage. A paradox is, thusly, revealed. Immigrants/ethnics should be represented in a project of national identity in the most meaningful, empowered manner but until they possess Hage's (1998) "governmental belonging" this is not possible. The campaign data revealed no evidence of "governmental belonging" in the form of immigrant/ethnic contestation of campaign bias/exclusion.

\section{The popular vote: White geography}

(The Popular Vote: The Sleeping Giant, Niagara Falls, Bay of Fundy, Nahanni National Park Reserve, Northern Lights, The Rockies and Cabot Trail - campaign material \#ix) 
Campaign rules suggested equal suitability of nominations for man-made or natural wonders. The top seven choices determined by popular vote are all natural wonders, thereby reflecting an ongoing attachment to Canadian geography and the notion of North. Early nationalisms, constructed with attention to fostering emotional attachment to particular geographies, have taken a kind of historic/a-historic hold for many Canadians (Osborne, 2001) and, I argue, are reiterated in the "Seven Wonders of Canada" campaign. It is this affinity for geography, as reflected by the popular vote and the short-list of fifty-two (campaign material \#x), that is, ultimately, of relevance to my argument that attachment to the historic geography of exclusion persists for many of the campaign participants even in the current context of multicultural ideology and policy. An analysis of the meanings attached to participant choices as evidenced in their commentary begins to demonstrate how the relationship between geography and national identity proscribes parameters of belonging and reflects power imbalances. Demonstrated in this section of the paper is the following: campaign participant propensity to superimpose notions of national identity onto geography, campaign participant relationship to the nation/geography in terms of inclusion/exclusion and the excluded Other in terms of strategies for belonging/representation.

Early in the campaign, Ian Clayton's comments on architecture in terms of "taking inventory of what we can do in this country" (campaign material \#xi) intimate that he imagined Canada's list of wonders might resemble the "New Seven Wonders of the World" list of manmade wonders. The criteria listed "spectacular physical site or amazing human creation" (see page 3 of Introduction for complete list) causing some confusion and anger from participants who thought the list should neatly be one or the other. In response to the "Seven Wonders of 
Canada" campaign, thestar.com architecture critic, Christopher Hume (campaign participant \#8), created his own list of seven man-made wonders, explaining,

To many, this country is its geography. But to those who know better, what defines Canada is less the land than our response to it. Above all, this means the incredible feats of engineering and construction required just to carve a nation out of the vast northern wilderness ...

How predominantly geography, itself, factored in the popular vote demonstrates that other campaign participants disagreed with this line of analysis. Campaign participant \#9's comment makes the connection between national identity and geography:

... if you believe that your physical landscape has a lot to do with the making of who you are then this list is a representation of the Canadian people themselves ... who they are, what they believe in and what they stand for. The list gives one a sense of place, a sense of what Canadians are all about.

The "Seven Wonders of Canada" campaign reveals that for many Canadians it is a response to the land that defines Canada but not in Hume's more intrusive, "man-conquers-nature" sense. It is rather in the sense of Eric Kaufman's (1998) "nationalizing of nature/naturalizing of nation" in which the meanings inherent in the construction of a national identity ascribed to a purified, ahistoric landscape appear natural. Campaign participant \#9's landscape "has a lot to do with" identity because meaning is ascribed to geography by people in the first place; in this way, as argued by Osborne (2001) there is a reciprocal relationship between people and geography. Once meaning has been so ascribed, geography comes to represent a certain commonality and to bind a particular group of people together. Geography is transformed into psychic space "that is profoundly integrated into peoples' identity" (Osborne, 2006, p.150). 
National identity, then, is a kind of collective memory in which meaning is attached to particular markers of identity, reflecting a set of values and ideals and evolving over time with a solid base in the past but modified as required over time (Osborne, 2001). Current day attachment to geography demonstrates that the past is not something finished and preserved; the past "is always being reconstructed in the context of the present and is never disassociated from consideration of power" (Halbwachs cited in Osborne, 2001, p.9). Just as British-Canadians at the turn of the twentieth century developed a "we are our geography/our geography is us" kind of national identity from their position of cultural centricity, it remains that at least some culturally dominant Canadians still feel that attachment. The meanings attached to geography inherent in early Canadian nationalisms were racist and proscribed notions of belonging; yet, because national identity was attached to geography, cultural dominance/subordination appeared natural. This still plays out, albeit more subtly. Campaign participant \#9's assertion of the connection between Canadian identity and the landscape assumes a "Canadian" cohesiveness that, historically, has never existed and that, currently, demands contestation.

Campaign participant \#10 observes that many wonders nominated by participants are located in Canada's geographic north:

The list of voter favourites included a disproportionate number of northern "wonders", including Dawson City, the Dempster Highway, ice roads, igloos, L'Anse Amour, Auyttuq National Park, Nahanni National Park, the northern lights, the Northwest Passage, the Porcupine caribou herd, the inuksuk and the Tuktoyaktuk pingos. I'm not sure if this represented a concerted effort on northerners' part to get on the list, or if people in Canada really think that ice roads are a "wonder" ...

I assert that campaign participant \#10 is correct that many Canadians, as reflected in the campaign, do think that ice roads, along with other representations of Francis' (1997) "cult of the 
North" (p.154), are "wonders". Francis (1997) argues that the North resonates as an important aspect of national identity for many Canadians regardless of place of residence or actual familiarity with northern geography - a testament to the power of early Canadian nationalisms and that the North is a cultural rather than geographic reference point (Shields, 1991). These early nationalisms, in which Canada's northern geography was attached to racialized notions of the white European as superior, promoted a monolithic Canadian national identity. "Canada First" as nationalism asserted that only northern Europeans could survive and flourish in the geography of Canada and, in turn, the geography strengthened and improved the character of northern Europeans (Berger, 1997). It aptly supported Canada's "presentist agenda" (Osborne, 2001) at the turn of the twentieth century in which white and British were valued above all else.

The conflation of geography and national identity demonstrated in the "Seven Wonders of Canada" campaign suggests notions of positioning and exclusion which, in the context of multiculturalism, are morally and ideologically problematic. Gregory Millard, Sarah Reigel and John Wright (2002) reference Pevere's analysis of Roots, an outfitter store which sells a vision of Canada along with its products:

A country as rugged and unspoiled as it is fragile and beautiful, vast expanses of green wilderness intersected by pure sparkling water systems... a country of canoes, cottages and campfires, where everyone spends a lot of time outdoors because outdoors is nowhere better than it is here...The mythic resonance of postcard Canada - the unspoiled hinterland... (p.19)

They argue that this particular notion of North resonates in English-Canadian popular culture; Roots uses the conflation of landscape and identity to sell to a particular group of "Canadians". Any suggestion that Canada's geography can offer a sense of cultural homogeneity is problematic (Manning, 2000). It is the culturally dominant who determine national identity in a 
self-serving manner and form a particular relationship to the nation. In this way, geography becomes culturally coded and "English-Canadian" identity conflates with ("real") Canadian identity.

Early nationalisms, linking "Canada" to northern geography with its meanings for virility and strength, asserted notions of superiority over anyone not white and "Canadian" also served in large measure to differentiate itself from southern, inferior United States (Francis, 1997). This notion of the United States as Canada's identity ex negativo (Lorenz, 2001) has become a longstanding nationalist trope, the prominence of which was demonstrated in the Seven Wonders campaign. Campaign participant \# 11 is one of many who espoused sentiment reflecting a desire for a national identity distinct from that of the United States:

I think they have completely missed the entire point with several of the wonders on the list. The Rockies, the Prairie sky, the northern lights, the igloo, and to an extent [Niagara] Falls are all shared wonders. Alaska would argue that the northern lights and the igloo are as much theirs as it is Canada's. Montana and North Dakota can lay claim to the Prairie sky. Montana can also claim the Rockies. I feel very strongly that if any of these true "North American" wonders make the list of Canada's wonders it would be a Canadian travesty. Judges: Please consider the true "Canadian" wonders ahead of those we share with our U.S. neighbours. Thank you.

The assertion of difference between Canada and the United States implies a particular Canadian homogeneity. In Manning's (2000) analysis of the I Am Canadian commercial, to be Canadian is to be like Joe, who is a white, English-speaking male who watches hockey and drinks beer; the commercial largely equates Canadian-ness with being decidedly not American. In taking on the job of asserting that Canada is different from the United States, Joe's version of how Canada and the United States differ suggests both a cultural homogeneity of which he is representative and a culture over which his group is dominant. Manning (2000) asserts that Joe's cultural references * 
for difference are between Canada and the United States, noting that a CBC program on the "I am Canadian" commercial came to the conclusion that Joe was representative of "us". If "being Canadian" means ascribing to the $\mathrm{CBC}$ version of "Canada", the notion of Canada promoted in the "Seven Wonders of Canada" campaign also alienates many. The widely embraced homogeneity promoted by Joe's nationalist stance belies the reality that not all Canadians are like Joe in their comfortable anti-American relationship to the nation. Manning (2000) argues that the matrix of inclusion/exclusion Joe's assertion represents obscures notions of belonging in the context of regionalism and multiculturalism.

A sense of connection to the land is captured in the following pitch for Cypress Hills, Alberta/Saskatchewan:

In the native grasslands you know that the earth you walk on has not been disturbed or torn up by man in over 70 million years. ... I return to the hills regularly to restore my soul and strengthen my roots to this marvelous land. (campaign participant \#12)

The notion of spiritual connectedness to the land suggests a sense of neutrality and accessibility that is belied by Osborne's (2001) argument that geography is "complicit in strategies of cultural survival". Campaign participant \#12's seemingly apolitical, spiritual connection to the native grasslands suggests a sense of Harmut Lutz' (2004) "palimpsest," that no one before him/her had attached meaning to the geography, or if someone had, it is erasable. As Manning (2000) argues, geography promises "a spiritual one-ness of nature and self" (para. 23) and "the mythical unity of a people who are created by the landscape they inhabit" (para. 23) by obscuring the historical fact of imperialism and racist nation-building. Francis (1997) quotes historian Arthur Lower 
whose description of a trip to James Bay touches on the notion of exclusionary aspects of a spiritual connection to geography:

Only those who have had the experience can know what a sense of physical and spiritual excitement comes to one who turns his face away from men towards the unknown. In his small way he is doing what the great explorers have done before him, and his elation recaptures theirs. (p.149)

In this passage geography begins to lose its neutrality insofar as it is associated with "great explorers". Such was the genesis of early nationalisms; "great explorers", white and male, appropriated both boat and land from indigenous peoples while asserting that British-Canadians had a particular spiritual relationship with the geography.

Campaign participant \#13 demonstrates spiritual relationship in the following pitch for Tofino, Vancouver Island:

Spectacular, breath taking, awe inspiring natural beauty. I love watching my dog and daughter frolic in the (freezing cold) waves during our yearly trek to Tofino - unfettered glee. A day at Long Beach washed away mundane worries, replenishes body and soul.

In this pitch, a particular, rather than universal, truth is reflected about the nature of these seasonal, redemptive journeys. Mackey (2002) quotes William L. Morton in the following passage:

Canadian life to this day is marked by a northern quality, the strong seasonal rhythm which still governs even academic sessions; the venture now sublimated for most of us to the summer holiday or the autumn shoot; the greatest of joys, the return from the lone savagery of the wilderness to the peace of the home; the puritanical restraints which masks the psychological tensions set up by the contrast of the wilderness roughness and home discipline. The line which marks off the frontier from the farmstead, the wilderness from the baseland, the hinterland from the metropolis, runs through every Canadian psyche. (p.45, as cited in Harcourt) 
However, in the midst of this "truth" is the problematic; fundamental questions immediately arise as to his particular meaning of Canadian in discussing life and psyche with respect to who is included and excluded. Shields (1991) argues that geographic/psychic North offers a kind of "disorder", redemptive for highly ordered societies - and in particular, the European psyche (p.191). In this analysis we are left with notions of a particular Eurocentric attachment to the North with decided parameters of national identity and belonging, that the North has a particular meaning only for the European. As argued by Osborne (2006), "established pneumonic tropes" (p.147) relate to historic values/meanings and are far removed from current notions of cultural identity and hybridity.

Francis (1997) asserts that for many Canadians upon entering "the canoeable Canadian landscape, we believe we are rediscovering and reinforcing our national virtues" (p.150).The following begins to further delineate that "Canadian" does not necessarily mean all Canadians. Campaign participant \#14, in telling a personal story about the Sleeping Giant, states,

Landscapes really impact ones whole being ... but of course all us paddlers [my emphasis] already know this

I argue that the "us" belongs to Bruce Erickson's (2008) "canoe nation", where the canoe, as marker of white, masculine national identity, exists in anachronistic, unchallenged space. This naming of "us" suggests presumably rightful attachment to a geography which separates "us" from "them" and reveals who has cultural power over whom. Using Hage's (1998) analysis of national belonging, "us paddlers" have "governmental belonging" with the authority to determine who belongs to the nation. As outlined earlier in the paper, one can possess this 
"governmental belonging" by having accumulated "national capital" which includes an attachment to dominant values. In this way attachment to a culturally coded geography established by English-Canadians, can also be accessed by "the large numbers of those of other ethnic origins who have engaged in the 'cultural convergence' of identifying themselves with English-Canadian values and myths" (Gwyn, 1997, p.278).

The mechanics of immigrant "belonging" are of interest to novelist, Shani Mootoo. In $\mathrm{He}$ Drown She in the Sea, "darker-skinned" Harry St. George from one of the Caribbean Islands was about to partake of the invitation to canoe at a mountain lake - "this was the Canada of postcards and tourism posters ... pride coursed through him; he had become an insider ... it would be very Canadian of him to be able to say that he used to get up early ... and go canoeing" (Mootoo, 2005, p.42-43). The character thusly acquires a measure of Hage's (1998) "national capital", the accumulation of which moves him from outsider to a position of belonging. In this way acquisition of "national capital" (Hage, 1998) and "cultural convergence" (Gwyn, 1997) become strategies of belonging. Equally important is the notion that it was upon "invitation" that the character was able to partake of canoeing in this very "Canadian" part of the nation. She, the inviter, in a culturally dominant position, has assumed the authority to include or exclude. The "Seven Wonders of Canada" campaign may have extended an open invitation to all "Canadians" to create a list that reflects "Canadian-ness"; I argue that the invitation covertly excluded those without a sense of Hage's (1998) "national belonging"

Campaign participant \#15 demonstrates a comfortable attachment to geography in the following pitch for the Rockies: 
... I thought my heart was going to leap out of my chest. The valley was laid out beneath us - and in every direction there were more and higher peaks, yet I felt I was truly at the top of the world. We sang, we laughed and cried and stayed as long as we could, just 'being' - wanting to prolong this, what was for me a deep spiritual experience, as long as possible.

This comfortable attachment to geography is not shared by all Canadians. Ambivalence toward this psychic space, with implications for contestation and new modes of inclusion in powerimbalanced, multicultural Canada, is evident in Manning's (2000) discussion of the art of the Group of Seven. Its prominent place in the construction of Canadian national identity as geography has remained constant; whatever other images windblown pine trees and rocky shield conjure, as the subject matter of many Group of Seven paintings, they have come to be a nationalist representation of Canada. Canadian geography with its historic meanings as best suited to virile, resourceful white men is evident in the following statement by Lawren Harris (Mackey, 2002 citing Berger, p.40):

It is only through the deep and vital experience of its total environment that a people identifies itself with its land and gradually a deep and satisfying awareness develops. We were aware that no virile people could remain subservient to and dependent upon the creations in art of other people's ...To us there was also the strange brooding sense of another nature fostering a new race and a new age.

Inference that Canadians are of a solitary, unified "northern race" is the stuff of nationalisms and nationalist paintings, in which human subjects are absent and where geography mythically unites. It is this historic conflation of identity and geography that is of interest to Manning (2000) in her analysis of the art of Jin-me Yoon. The motivating issue behind Yoon's work is whether she, as a non-Western woman, can enjoy a connection to the Canadian landscape. In "The Group of Sixty-Seven", images of sixty-seven members of the Vancouver 
Korean community are superimposed on the unpopulated art of Lawren Harris and Emily Carr, thereby de-territorializing landscapes which had been previously appropriated by "white" Canada. In so doing, Manning (2000) argues, Yoon challenges the viewer to reflect on how immigrants can be integrated into iconic, white/White landscapes which to this point have paid little attention to "exclusions within the public sphere of migrant and immigrant populations, racial oppression, gendered and sexist expressions of the land or the attempt to annihilate native lands and customs" (Manning, 2000, para.30).

Manning (2000) further argues that the art of the Group of Seven must be understood on its own terms; it reflects an historic nationalizing effort which had no reasons to address the issues inherent in white/Other relations. It currently becomes a conduit for critique of identity in multicultural Canada, in which the conflation of identity and geography is challenged and landscape is recognized as an instrument of cultural power. As argued by Osborne (2006), representation in the public spaces of culturally plural Canada is a site of contestation rife with "complex ambiguity" (p.159), where power imbalances pose serious challenges to the "deep cultural diversity" espoused by Hage (1998). Yoon is aware of the imbalance of power in the relationship between the cultural centre and herself - and has to some degree neutralized it.

\section{The final list: nationalist tropes and strategies}

The judges included natural wonders in their final list (Niagara Falls, Prairie Skies, The Rockies, Old Quebec City, Pier 21 - Halifax, The Igloo and The Canoe - campaign material \#xii), ensuring a certain "geographical correctness" (campaign participant \#16) by choosing wonders to represent every region in the country - and with last-minute drama pronouncing that 
the canoe represents all of Canada. The judges were obliged to work within the parameters of designated criteria in choosing from the original 25,000 nominations. Despite having the authority to select at will, it might be supposed that they felt some measure of pressure to at least keep the popular vote in mind while determining the final list of seven. I look for socio-cultural meaning in the judges' choices, how their list of seven differs from the popular vote. Reflected in the popular vote, is the desire of the campaign participant, who I argue is part of mainstream Canada, to have him/herself represented, to maintain cultural centricity. The selection process has been described earlier in the paper and reflects the notion that the judges "know" better than the participants. An analysis of what the judges "know", how their list differed from the popular vote reveals two nationalist tropes: regionalism and multiculturalism. The broader meanings of these tropes are extrapolated from the "Seven Wonders of Canada" campaign for consideration in this section of the paper. Participant commentary, crucial to a general discussion in support of this analysis, also reveals much in terms of whom the participants are and how they view their relationship to both the nation and Other.

The final seven choices were marked on a wall-sized map, speaking to the emphasis the judges placed on equal representation by region. Campaign participant \# 17's comments begin to analyze this attention to regionalism:

You will note that the judges managed to include a wonder from every province and territory, despite the fact that there are 13 provinces/territories and only 7 wonders. You have to give them diplomatic respect - with the igloo, they chose a wonder than spans all of northern Canada and with the Prairie skies, they chose a wonder that spans 3 provinces. They also managed to choose one wonder which all Canadians can relate to the canoe. With Quebec City, they managed to appease the French heritage of our country and by including Niagara Falls, they avoid the moniker of leaving out a natural world wonder from the Canadian wonder list. Yes, the judges certainly managed to create a list that is distinctly Canadian. 
Campaign participant \#16's attitude toward the judges' efforts is critical:

The project lacked focus and tried too hard to fulfill the CBC mandate to reflect us to us "coast to coast to coast". Thus we had the [judges'] confessions of "geographical correctness" on Thursday [morning's] SLC (Sounds Like Canada).

Campaign participant \#16's comments intimate that the judges incorrectly thought that emphasis on regional representation was essential to creating a list of seven "wonders" which reflect "Canadian-ness". This campaign participant is not so certain that the judges should be reflecting "us to us"; there are many campaign participants who articulated the idea that "we" could have done better, that the popular vote reflected a "truer" Canada. This is discussed in detail later in the paper. What becomes clear in the following analysis of representation is that the judges' attention to region did not appease campaign participants. Because the judges were perceived to have a biased attachment to a particular part of the country, participants from other parts of the country felt unrepresented.

The campaign assumed a competitive quality for many participants. The "competition" appeared copasetic among a few of the prominent contenders:

I agree Niagara Falls should be on top. Bay of Fundy has an alphabetical advantage in that it's first on the list. (campaign participant \#18)

I can understand your disappointment that Niagara Falls was not number one. I really can't even understand why the 1000 Islands didn't even make the list ... I'm very disappointed that it didn't. (campaign participant \#19)

The "competition" became quite acrimonious toward the perceived judge bias in favour of southern Ontario and Toronto: 
... Because here in the north we love being an afterthought, and we love it when you tell us that you're only including us because you think you have to. (campaign participant \#20)

I am saddened to join the naysayers in my community who declared that it was a foregone conclusion that this area would never make the final 7 once it was determined that 2 of the 3 judges were from Southern Ontario. (campaign participant \# 21)

... It would not matter a whit if Thunder Bay had 1 or 50 of our national treasures. The political rules are "Nothing goes to a place like Thunder Bay". (campaign participant \#22)

The federalist predisposition to region over nation, with concomitant asymmetric power distribution, generates widespread attachment and antagonism toward particular regions throughout the country (Nurse, 2002). I argue that the authors of the above-noted negative commentary are part of a self-asserted, culturally central "us" who are voicing their anger at the judges, perceived to represent south/ Southern Ontario. In attaching themselves to sub-national allegiances, the nation as a primary site of identity is, thusly, compromised; the "emotional and sentimental glue" (Hosti in Osborne, 2001, p.7) of nation is less binding.

Within the context of the "Seven Wonders of Canada" campaign, mainstream Canadians in particular regions of the country have made a shared issue of unequal power and representation with other mainstream Canadians. Campaign commentary reflects that a connection, whether positive or negative is between a particular group of Canadians with representation issues attached to region. Unequal power and representation are an issue for immigrants at a more national level. A certain level of Hage's (1998) national belonging is requisite before one feels a sense of regional belonging; as noted in Nurse's (2002) example in which Chinese-Canadians in Western Canada think of themselves as Canadian or ChineseCanadians rather than Westerners. In this analysis, exclusion is internalized. The discussion on 
regionalism presumes homogeneity, that this is the issue for "Canadians"; anyone for whom this is not an issue is excluded. Immigrants, ultimately, are represented by Pier 21 but this is a most convoluted representation. Considerable discussion on how Pier 21 represents immigrants follows later in this section but at this point it is important to note that Pier 21, too, became part of the regionalism paradigm insofar as it was seen to represent a region of the country. The wonder that represented immigrants also represented the Maritime Provinces.

In ensuring that all regions of the country were represented, the judges added Old Quebec City, the igloo (representing a change from Haida Gwaii, which, otherwise would be on the list of seven) and Pier 21, as mentioned above. In deference to other potential final choices, campaign judge MacGregor was prepared to forgo the canoe as his first choice, stating that it "doesn't really belong anywhere except in our minds" (campaign material \#xiii). The canoe then moved from a virtual non-choice, because it didn't fit into the judges' paradigm of attaching "wonders" regionally, to a position of representing all of Canada that worked well for campaign organizers. Surmising that "the canoe has slipped quietly into the stream of the nation's common parlance", promotional material for the project queries, "what better than the canoe to stand for everything Canadian" (campaign material \#xiv). All of these choices fit into a paradigm of multiculturalism ${ }^{6}$; at first glance, the problematic surfaces in terms of juxtaposition. "Canada", the whole, is represented by the canoe but there are implications for the others in terms of their representation as separate or as part of Canada.

\footnotetext{
${ }^{6}$ First Nations, Metis and Inuit are not usually part of a multicultural paradigm but insofar as they are nations/groups within the framework of the plurality that reside in geographic Canada ... indigenous people are part of my argument.
} 
What does it mean, then, to say that the canoe represents all of Canada while the others represent regions within Canada? The judges may have had some notion of unity in mind; however, it is the very ambiguity in the meaning of a concept such as "the-canoe-as-Canada" that enabled and enables English-Canadians to conflate English-Canada with Canada and to maintain Mackey's (2002) elusive, White power in the management of diverse populations. It is interesting to note that the very material promoting the-canoe-as-Canada is titled "The Canoe, Ontario" (likely unintentionally) which begs theoretical discussion then not only on the conflation of English-Canada as Canada but also of Ontario as Canada in a regionalist context. As noted by Nurse (2002), historically, Ontario has not been viewed as a region but rather as the "heartland" of Canada, the core that dominated the peripheries - representing a conflation of Ontario and Canada (p.19).

Campaign participant \#23 rightly questions the asserted relevance the judges have attached to the canoe:

"I canoe but give me a break, how many Canadians have been in a canoe ...".

I argue that having been in a canoe is not the point, that the canoe and the northern landscape represent psychic space that has meaning for many Canadians ${ }^{7}$. In its telling of the Seven

\footnotetext{
${ }^{7}$ Francis identifies the importance of the canoe as marker of national identity, noting that the "Spirit of Haida Gwaii" (a sculpture of a canoe carrying a multitude of characters from Haida mythology) is prominently situated at the Canadian embassy in Washington D.C.
} 
Wonders of Canada story, CTC (Canadian Tourism Commission) ${ }^{8}$ asserts the importance of the canoe in its catch-phrase,

Canada: I Canoe, therefore I exist. To Canadians, the canoe says it all: Aboriginal heritage, the history of a nation, European voyageurs. (campaign participant \#24)

If one does not canoe or if the canoe with its meanings for "Aboriginal heritage, the history of a nation, European voyageurs" does not resonate, one is not "Canadian". More to the point and using the One-Other paradigm, One is "Canadian"; the Other, for whom the canoe does not have the same meanings, is not. In the language of metaphor, the $\mathrm{CBC}$ observation:

if it weren't for the humble canoe, half the wonders on this list would be inaccessible! (campaign material \#xiv)

becomes Bannerji's (2000) observation that Whiteness "is the point of departure for "multiculture"” (p.110). As argued by Hage (1998), Whiteness asserts that a multicultural mix is best guided by a "White essence" which has the ultimate authority to manage otherness. Implications of this analysis for indigenous peoples, Quebecois and immigrants are discussed in the paragraphs that follow.

Campaign participant $\# 25$ discusses how the igloo was chosen with readily apparent disdain for unfair/immoral treatment of indigenous peoples:

The judges provided an insightful explanation for the last item. They picked out seven wonders and marked them on a map. Then they realized that they did not have any wonders in the north. So they suddenly changed their minds and decided that the igloo should be a wonder, too. ... You might be wondering which wonder got the axe [or ulu, in this case] to make room for the igloo. It was Haida Gwaii, of course. If CBC is going to celebrate one aboriginal culture, another aboriginal culture is just going to have to

\footnotetext{
${ }^{8}$ The Canadian Tourism Commission is a marketing organization whose mandate is to support the growth * and profitability of the Canadian tourism industry.
} 
move out of the way. Don't worry. They'll give you blankets and five dollars each. Have your chief sign here, please. ...

I firstly comment on the imperative that indigenous culture be represented in some manner in the final list. Making indigenous culture "Canadian" "provides a longer continuum and tradition of culture for the nationalist cause" (Mackey, 2002, pp.77-78) and helps the cultural centre "to resolve their lingering sense of not belonging where they need to belong" (Francis quoted in Lutz, p.173). On the Haida Gwaii-igloo debate, campaign participant \#26 commented,

So, they gently removed the Haida Gwaii (Queen Charlotte Islands), confident that aboriginal heritage was left intact".

That this was said without apparent irony speaks volumes and becomes a metaphor for the propensity of Canadian nationalisms to manipulate cultural representations. Mackey (2002) argues that the actual exclusion, marginalization and erasure of indigenous peoples, is reflected in nationalist narrative in whatever manner suits the nationalist agenda of the period. Current assertions of constitutional rights by indigenous peoples to renegotiate land treaties are tempered by a nationalist discourse which relegates the indigene to an environmental context, as "guardian of the land" able to inspire harmony with nature (Mackey, 2002). The appropriation of indigenous notions of respectful attachment to the land; however, does not alter the reality that the power to manage the geographic space of "Canada" continues to be withheld from indigenous peoples. It is mainstream Canadians who possess this power over the Otherindigene, Quebecois and immigrant - and use it in the management of national space.

As noted by campaign participant \#27, Old Quebec City was chosen with attention to FrenchEnglish politics: 
because you can't forget Quebec or they'll threaten to leave. Being a Canadian is like being in a dysfunctional marriage: 'I hate you! I'm leaving! But - ' *SLAM*.

English-Canada is mindful of two things: the precarious relationship between itself and Quebec and that its notion of Canada includes Quebec. Quebecois politics has historically made it clear that inclusion in Canada on English-Canadian terms is not its goal. On one side of the issue, Quebecois politics calls for acknowledgement as nation/distinct society. On the other side of the issue, EnglishCanada imagines Quebec as part of Canada and can justify/rationalize special status related to Quebec's historic role as co-founder of the nation. This augurs for a convoluted notion of national identity; resolution au moment centres on the notion of Quebec as nation within a nation. When campaign participant \#28 allows that:

with Quebec City, the judges managed to appease the French heritage of our country,

it is an English-Canadian sense of "French heritage" that is appeased, paralleling the above paradigm in which Canada needs Quebec as part of its national identity but Quebec does not need Canada as part of its sense of nation. As argued by Juteau (2002) the Quebecois negotiate with English Canada from a political position of cultural homogeneity and geographic attachment to Quebec as place. It is this ethnic nationalism which multiculturalism, as "model of civic nationhood" (Mackey, 2002), threatens; Canada as a multicultural/racial "mosaic" undermines the separatist aspirations of Quebec, thereby maintaining an English-Canadian notion of Canada. Quebec becomes one part of Canada the whole in campaign participant \#29's unofficially proposed wonder:

the Canadian ability to unite Newfies and Quebecois in a single national identity ... (well, sort of ...)

leaving Quebec no more distinct than other ethnicities or regions of the country. 
Campaign participants made the following comments about Pier 21, historically a gateway to

Canada for immigrants, currently a museum:

After 55 years in this wonderful country, there is still nothing that grabs my soul, my imagination, puffs out my chest and yes, even brings a little tear of joy to my eyes, than walking through Pier 21 's doors onto the sacred ground that made it possible for me to become a Canadian. (campaign participant \#30)

Promotional material for the museum continues in a similar vein:

... one in five Canadian families has a link to Pier 21, the immigration shed that welcomed more than a million immigrants - refugees, troops, war-time evacuees, war brides and their children - to Halifax over 41/2 decades. (campaign participant \#31)

... the people who passed through its gates comprised " a mosaic of different nationalities and cultures that have made Canada such a diverse country - country which promotes human rights and the equality of life and opportunity". (campaign participant \#32)

These observations and assertions, rife with notions of civility and tolerance, begin to inform the disconnect between multicultural ideology and practice. Multiculturalism, as nationalism, promotes Canada as a "model of civic nationhood" (Mackey, 2002) and like the above comments exemplifies a nationalist propensity to forget or rewrite racist elements of Canadian history. The four and a half decades during which Pier 21 "welcomed" immigrants were 1928 to 1971 (campaign participant \#33); it wasn't until 1967 that racist language was removed from immigration regulations and policy overtly reflected a welcoming of diversity. In early immigration schemes, immigrants were included insofar as their presence meant potential contribution to the economy but excluded socially - representing a positioning. For the most part it was European immigrants who landed at Pier 21; if Pier 21 represents immigrants/diversity, it represents particular groups of more easily assimilated immigrants. The museum offers a promise of telling the whole immigration story; even in this eventuality, the psychic space of 
"museum" represents a limited sense of national belonging. Even with the removal of racist language from immigration regulations, the "official" welcome to immigrants of any ethnicity is quite different from Hage's (1998) practical-cultural national acceptance. This practical-cultural acceptance unfolds at a "communal, everyday level" (Hage, 1998, p.51) in a real, rather than a legislated, theoretical way.

Demonstrated throughout history, and in the above examples, is the ability of dominant Canadian culture to position itself and other groups in ways that perpetuate its location at the apex of power. Canadian multiculturalism institutionalizes difference; Mackey (2002) acknowledges Asad in arguing that the cultural centre has strategic value. Mackey's (2002) "Canada 125" identified a schism in the small communities where she conducted her research. With great frequency "Canada 125" celebrations were divided into multicultural and unnamed. If it is presumed that the unnamed celebrations are "Canadian," the multicultural celebrations represent something else - not quite Canadian. Immigrants/ethnics are placed in a "distinct cultural space" as Other, juxtaposed against the unmarked normative space of Whiteness ultimately associated with the multicultural state of Canada rather than to the local nation of Canada (Mackey, 2002). Peake and Ray (2001) argue that these wanted/unwanted immigrants are part of a racialized discourse which places them outside of the nation - as negative disruptions to the "real" Canada, the vestigial "great white north" which lies in demographically white countryside and small towns. This positioning reflects ambivalence: immigrants wanted for economic and cultural contribution unwanted as threat to national identity. Hage (1998) argues that positioning immigrants/ethnics "in the liminal space of the not too excluded, but not too included either" has been institutionalized by White multiculturalism. 
If multiculturalism is strategy to keep Gwyn's (1995) English-Canadians and "the culturally converged" in the cultural centre, the issues of the "strategists" require consideration and are briefly explored here. Troublesome is Gwyn's (1995) assertion that English-Canadians deserve to be in the cultural centre as evidenced in the following:

It was English-Canadians who explored the greater part of the country, cleared it, and settled it. It was they who contributed the overwhelming majority of men who died fighting in wars for democracy and freedom. It was they who created almost all of the country's political and legal infrastructure (borrowed from Britain of course, but substantively amended here) and who established the social security systems that make this country distinctive in North America. It was they who developed the prevailing mores of civility and tolerance towards pluralism and diversity that make this country unlike any other in the world. (p.113)

He incorrectly conflates contribution with entitlement, conveniently overlooking, for example, the contribution Chinese workers made to the construction of the Canadian Pacific Railway. He further argues that named minorities are afforded rights - and means of recourse when these rights are infringed upon - that English-Canadians are not. This along with affirmative-action initiatives result in claims of "white disadvantage", an argument for which Mackey (2002) states there is no statistical basis. In his analysis of "white decline" Hage (1998) describes the phenomenon whereby white people without "national capital" experience a sense of power in sharing a cultural identity with those who possess it; the perceived potential to acquire this "national capital" via cultural attachment is threatened as visible minorities become part of the middle-class that to them remains elusive. One of Gwyn's (1995) stronger points may be that English-Canadians have no sanctioned outlet for dealing with how cultural pluralism has affected the centrality of their position within Canadian culture. Hage (1998) asserts that dealing preemptively with the sense of "national loss" would minimize racialized backlash. To this 
assertion that English-Canadians have no sanctioned outlet, I argue that the "Seven Wonders of Canada" campaign, and the participant responses to it, represents a self-sanctioned outlet. Canadian-Canadians were dialoguing about their version of Canada with no apology for selfcentredness. Whatever share of national space may be allocated to immigrants by the EnglishCanadians participating in the "Seven Wonders of Canada" campaign, new immigrants/visible minorities are not part of the process or dialogue.

In this sense, then, in choosing the canoe as a wonder to represent all of Canada, the judges proscribe parameters of belonging; those who ascribe to the values and myths of Gwyn's (1995) English-Canadians are welcome to participate in the project of the nation, albeit a project representing an a/historic notion of nation. National space, as argued by Hage (1998), is frequently imagined and formulated as a desire "to return to what the nation used to be"; "canoe nation", as nationalism, makes clear who is "Canadian". The importance of the canoe is asserted by campaign participant $\# 34$ :

I'm happy to see that the canoe finished in the top 7. If this contest had been held about 25 years ago I don't think the canoe would have finished in the top 20. To me this shows how Canadians have changed their thinking, we have become more Canadian.

Gwyn (1995) discusses the disenfranchisement felt by many English-Canadians, who are "grieving the loss of their familiar world" (p.281). So, put another way, perhaps certain Canadians are asserting the brand of nationalism that the canoe represents because their cultural centricity and power are in jeopardy. 


\section{Reaction to the final list: "the people" and notions of centre/periphery}

Any moral authority attached to multiculturalism becomes further suspect when tolerance as national characteristic is analyzed. Multiculturalism's call for tolerance quickly reveals underlying intolerance, insofar as the "tolerator" has the power to revert to intolerance at will; as further argued, this intolerance is not a manifestation of racism so much as it is a racialized nationalism in which the "tolerators" are executing their power to determine who is attached to what part of national space (Hage, 1998). The following comments by participants speak to who ideally should not have to be tolerated or allotted a share of national space within the context of the "Seven Wonders of Canada" campaign:

This is a distinctly Canadian list. And I'm saying that with a sneer. We need something that represents immigration, French culture and [Aboriginal] culture. We can't have too many "wonders" from the same region. (campaign participant \#35)

A consideration of who campaign participant \#35's "we" are reveals the notion of the ability to manage national space. "We" can address immigrant, French and indigenous representation or not. Hage (1998) clearly demonstrates that this "we" represents an extrinsic relation, noting the difference between "we have diversity" and "we are diversity" (p.139). "We" as extrinsic allows the mainstream to reproduce itself (Hage, 1998) while positioning the Other. The selection of Pier 21 to represent immigration reflects an extrinsic relation between English-Canadians and new immigrants/ethnics. Agreeing and disagreeing with campaign participant \#35, campaign participant \#36 asserts:

Why do Canadians always make excuses for banality and lack of creativity by saying "It's so Canadian". I think it's a CBC disease, not a Canadian disease. CBC has its uberPC mandate which takes the edge off everything it touches. (The list, for [example]) Because Canadians have so little else to connect each other, they start believing the bland notion of The Canadian fed to them by the CBC. Canadians don't have to be "nice" or "so Canadian" in order to justify themselves. We have much more going for us than that. 
Participant \#36 distances him/herself from the $\mathrm{CBC}$; he/she has the authority to be nice, to include or not be nice, to exclude - and does not need the $\mathrm{CBC}$ to dictate how to manage national space. Paralleling Hage's (1998) analysis, the project judges have, with their choices, provided a multicultural list, calling for inclusion, representation and "tolerance". Some participants exercised their will to reject this multicultural representation; in the role of "governing subjects", these participants assumed the authority to manage national space. Despite the known-from-thebeginning stipulation that the judges had the final authority to compose the list with deference to "diversity", considerable anger was articulated when Sleeping Giant, with the most popular votes, wasn't chosen by the judges and a few examples are copied here:

The fact that the votes on this "people's choice" wonder didn't count in the judges minds, also helped turn this contest into a farce. (campaign participant \#37)

... The seven wonders your judges chose are their wonders, not the even wonders of Canada. ... I think CBC should do the right thing and do away with the judges choices and replace them with the people's choice. (campaign participant \#38)

This should be renamed "The judges 7 wonders" and give us a chance to have a real Canadian 7 wonders. (campaign participant \#39)

This is a complete parody of the CBC itself - a predetermined cultural agenda run roughshod over the real cultural points made by Canadians themselves. Thanks for your ideas Canadians, but the $\mathrm{CBC}$ alone knows what is wonderful about this country. (campaign participant \#40)

It is clear that these participants do not think that the $\mathrm{CBC}$ is representing their version of "Canadian". These assertions of "real" Canadian and "the people" are part of Mackey's (2002) new-Right discourse, in which "the people" are constructed as a non-political category of authentic citizens (p.117) who stand in opposition to the political correctness of the intrusive state. In this version of populism, "the people" view themselves as real, authentic Canadians able 
to articulate democratic will and to define who is included and excluded in the nation (Mackey, 2002).

The following dialogue demonstrates notions of authority and belonging between an American and a Canadian. An American (campaign participant \#41) offers her suggestions for the list of the seven wonders and shares that she was made an honorary citizen of Canada in a bar. To this, a Canadian, campaign participant $\# 42$, suggests that since she is an honorary Canadian she might wish to consider becoming a Canadian citizen. The cultural commonality is manifested internationally and parallels Robin Cohen's (1997) analysis of cosmopolitan cities, in which these cities are more closely connected to each other than to the "hinterland" of the nationstate where each is geographically located (p.167). However, this interconnection is not between the citizens of cosmopolitan cities in the usual context of globalization but rather an interconnection between Hage's (1998) "governmental subjects" from two countries of immigration who have the "authority" to establish cultural attachment and national belonging. In the context of the "Seven Wonders of Canada" project, with its implications for nationality identity, intranational disparity and difference is once again hinted at. In this dialogue the "we" suggests a sense of attachment based on other than national boundary and has exclusionary implications for the "they" within Canada who are not part of the dialogue and possess a less central place in the national imaginary.

Campaign participant \#43 reacts to the judges' presumably misguided attachment to Toronto: 
Get out of Toronto on occasion and once the smog leaves your eyes ... you may actually see there is world outside that dying area.

What is "dying" in Toronto is a sense of Canada as mono-cultural. As a cosmopolitan city of immigration, Toronto is one of several sites where "liberal multiculturalism is transmuting into a hybrid pluralism" (Osborne, 2006) and where Bhabha's "third space of enunciation" challenges nationalist interpretations of the nation. Insofar as traditional notions of national identity are challenged by the many impacts of globalism and trans-nationalism, those espousing traditional notions react. Following Osborne's (2006) analysis in which "the local and familiar" are defended over the global, campaign participant \#43 embraces his traditional Canadian "world" while dismissing Toronto cosmopolitanism with acrimony. In Hage's (1998) analysis of White multiculturalism, many who claim a right to "governmental belonging" feel that multiculturalism has undermined their authority as "national managers". He argues that there exists a schism between the "White cosmopolite" who knows how to appreciate and consume ethnic culture and the more traditional national subject who does not. Hage (1998) argues that it is only when juxtaposed against ethnocentrism that this "enriching" aspect of multiculturalism appears positive; the problematic is readily apparent when the "enriching/enriched" dichotomy is considered.

The "cosmopolite" - with his/her more sophisticated socioeconomic, educational and cultural background - invites the ethnic Other into national space that had previously been controlled by the traditional national subject who does not possess the same ability to embrace or govern Otherness (Hage, 1998). In the world of cultural politics, Hage's (1998) “cosmopolites" and Mackey's "real" Canadians vie for supremacy. Both view themselves as governmental 
subjects and immigrant others as objects - for "cosmopolites" as objects to be comfortably positioned and managed and for "real" Canadians as objects to be uncomfortably managed and minimized as a perceived threat. In the context of globalization and cosmopolitanism, the "cosmopolite" views him/herself as the centre and the provincial hinterland as the periphery. The "real" Canadian views him/herself as what rightly should be the centre (and what undoubted does feel like the centre in small town Canada and pockets in urban Canada), a status that has, in his/her mind, been misguidedly thwarted. Insofar as both identities are constructed based on an objectified immigrant Other, they are, in Hage's (1998) analysis, "fantasies of white supremacy."

\section{The campaign ends: the CBC's apology and my concluding comments}

Several campaign participants offered social commentary on Canada's national identity via "outside-of-the rules" lists of seven "wonders". Two are listed here:

The word sorry [my emphasis]

The shovel, for use on both snow and bullshit

A bone, to toss to aboriginal leaders when they threaten to set up a blockade

Canadian flags, to hang all over Quebec in hopes that they won't leave

The phrase, "At least we're not as bad as the States"

Waiting rooms in the emergency department at the hospital

The SUV, for navigating the drive-through at Starbucks (campaign participant \#44)

And from a person identifying herself as American:

Having any identity at all

More than two hundred years since a U.S. invasion

That the beer is considered good

That the country is considered liberal by U.S. conservatives

That more people live in California than Canada

That they have a monarch as head of state

That they still "like Americans, sometimes, well often. No really, sorry if I offended you. Oh pardon me really" [my emphasis]. (campaign participant \#45) 
Commonality in these offerings is noted with respect to the notion of "Canada" as apologetic. At the campaign's end the CBC does not disappoint. It apologizes:

"If you were disappointed with the Seven Wonders of Canada ... We truly regret you are disappointed ... we obviously feel terrible that such a project would lead to anger ... (campaign material \#xv)"

In its essence, the CBC apology acknowledges that the participants didn't agree with/didn't understand the "announced-from-the-beginning" rule that the popular vote would not determine the final list of seven. This paper has already addressed the "popular vote" issue using Mackey's (2002) analysis of anti-government new-Right discourse; I argue that the CBC was apologizing for the wrong transgression. In culturally plural Canada, the $\mathrm{CBC}$ has promoted a project of national identity which systemically excluded the Other from the campaign process and from representation in the final list of "Seven Wonders". In conflating "Canada" with a CBC/White Canada, the campaign, while apologetic to the people who were included, remains oblivious to those it excluded.

The point made by several participants remains valid: that a popular vote would not work - seemingly demonstrating the impossibility of arriving at a truly well-represented and representational notion of national identity. I like campaign participant \#46's query as to

why the limit of [seven]. Start a list and add to it ...

In an anti-palimpsest manner, history is not erased and national identity becomes an "add-to" proposition. As argued by Veronica Strong-Boag (1994) "If it is to be fully told, our history needs many interwoven narratives where none ... excludes the others". This is a start but does 
not resolve the current realities of power imbalance and hegemony - in terms of which "Canada" has the most viability and whose "Canada" does not want to relinquish its centricity. As it presently stands, the CBC is in a very central position to create/reflect/re-create $a$ pulse of "Canadian" culture. Using the analysis of both Hage (1998) and Mackey (2002), this paper has demonstrated that $\mathrm{CBC} /$ White Canada maintains its location in the cultural centre using strategies that promote the very naturalness of its position. If CBC Canadians are part of this essence of White - the cultural ideal - so, also, are many other groupings. White is not homogenous except in its location and ability to exclude and, more frequently, position the Other. This ability manifests itself in the creation of class differentiation - a class with "national belonging" and capital that positions and exploits, at will, another class for its contribution of labour to the economy and of culture to the centre's sense of recreation. As argued by Bannerji (2000) and others, this class distinction is racialized - magnified by multiculturalism's discourse of the valuation of cultural difference, made static and undermined by the notion of "visible minority". Awareness of these racialized power imbalances moves to the forefront a kind of class struggle; an an sich sense of oneself in and of itself is transformed by a fur sich awareness of itself in relation to others. Just as Jin-me Yoon's art represents an awareness of and protestation against exclusion from White geography, the following quote demonstrates an awareness of and protestation against the cultural centre's attempt to position the immigrant/ethnic in national space:

I came to Australia twenty-six years ago. I was twenty. I love Lebanon and I love Australia and that's how it is. What I can't stand about Hanson is that she thinks that I have to choose. Actually ... no ... let me rephrase this. What I can't stand is her acting as if I have to give her some account about how Australian I am. You know that really irks me. It's not when she's going on about how there are too many migrants, and all that stuff, that upsets me. It's when she says "I don't consider migrants anything other than first class citizens." This really gets to me, you know, as if she's doing me a favour or 
something. I mean who the hell is she to consider me or not consider me. I certainly don't need anyone like her to tell me whether I am a nice Aussie boy or not. I am an Australian and that's all there is to it. Look ... I have two boys, one is seventeen and one is nineteen and, if ever there's a war, they are the ones who will be fighting for this country. So really, I wouldn't even have Howard question or supervise how Australian I really am, let alone Hanson. (quoted in Hage, 1998, pp.227-228)

I return to a quote located in the introduction to the paper in which Shields (1991) argues that "...the view from the margin becomes the only determinant of universally-binding truth" (p.277). The periphery's awareness of its power-imbalanced relationship to the centre is far truer than the centre's nationalist propensity to concern itself with power and control. In this position, the only truth reflected in the CBC's "Seven Wonders of Canada" campaign is its attempt to perpetuate a White Canada notion of itself. Borrowing from Shields (1991) and Mackey (2002), I argue that the cultural centre does not/cannot afford to embrace universal truth if it wants to maintain its centricity.

Several subjectivities have been addressed in this paper. Mackey's (2002) CanadianCanadians think that their "small-town" Canada represents the real Canada just as the White/CBC participants and judges in the "Seven Wonders of Canada" campaign think that their respective notions of Canada are correct. Hage's (1998) cosmopolites would have a totally different notion; the lived realities in Canada"s cities of immigration often have little in common with those of the hinterland. Immigrants with or without transnational ties have a different view, one that likely represents Shields' (1991) "universally-binding truth" from the margin. Cultural pluralism is the reality; the multi-cultures are represented in larger numbers causing Hage (1991) to posit the notion of "white-decline". Talal Asad asserts that there are radical aspects attached to cultural hybridity (in Mackey, 2002), which Mackey (2002) argues do not threaten to disrupt 
current power imbalances. Current demographics and the passage of time; however, do augur for a more equal distribution of cultural power. Canada's notorious preoccupation with national identity may not be a bad thing; talking about these issues is important - as long as everyone is talking. 


\section{Appendices}

\section{Object of study lists}

The following lists represent the data extracted from the campaign and used in my analysis. The first list is comprised of material generated by the CBC. At times, this information was located at a location other than a $\mathrm{CBC}$ website, quoted from the $\mathrm{CBC}$. The second list is comprised of participant responses to the campaign.

A] "Seven Wonders of Canada" campaign material:

\#i Day 7: The Origin of The Seven Wonders of Canada Project. Shelagh Rogers interviews Ian Clayton [audio] - located at http://origin.www.cbc.ca/sevenwonders/sounds like canada.html accessed 28/03/2008. (p.2)

\#ii More on the Seven Wonders of Canada - located at

http://www.cbc/national/blog/content/editors blog/more on the seven wonders of $\mathrm{c}$ accessed 28/03/2008. (p.1)

\#iii The Judges - located at http://www.cbc.ca/sevenwondres/the judges.htm1 accessed 28/03/2008. (p.1)

\#iv CBC's Seven Wonders of Canada - located at http://www.cbc.ca/sevenwondres/index.html

\#v The Criteria - located at http://www.cbc.ca/sevenwonders/criteria.html accessed 28/03/2008. (p.1)

\#vi More on the Seven Wonders of Canada - located at http://www.cbc/national/blog/content/editors blog/more on the seven wonders of $\mathrm{c}$ accessed 28/03/2008. (p.2)

\#vii The Judges - located at http://www.cbc.ca/sevenwondres/the judges.html accessed 28/03/2008. (pp.1-2)

\#viii. More on the Seven Wonders of Canada - located at http://www.cbc/national/blog/content/editors blog/more on the seven wonders of $\mathrm{c}$ accessed 28/03/2008. (p.2)

\#ix Seven Wonders of Canada - located at http://www.answers.com/topic/seven-wondres-ofcanada? cat $=$ travel accessed 28/03/2008. (pp.1-2)

\#x Seven Wonders of Canada - located at http://www.answers.com/topic/seven-wondres-ofcanada? cat $=$ travel accessed 28/03/2008. (pp.2-3) 
\#xi Day 7: The Origin of The Seven Wonders of Canada Project. Shelagh Rogers interviews Ian Clayton [audio] - located at http://origin.www.cbc.ca/sevenwonders/sounds like canada.html accessed 28/03/2008. (p.2)

\#xii Seven Wonders of Canada - located at http://www.answers.com/topic/seven-wondres-ofcanada?cat=travel accessed 28/03/2008. (p.1)

\#xiii The Seven Wonders: Did the judges miss the boat ... er, canoe? - located at http://www.insidethecbc.com/7flawedwonders accessed 28/03/2008. (p.1)

\#xiv The Canoe, Ontario - located at http://www.cbc.ca/sevenwonders/wonder canoe.html accessed 28/03/2008. (p.1)

\#xv More on the Seven Wonders of Canada - located at http://www.cbc/national/blog/content/editors blog/more on the seven wonders of $\mathrm{c}$ accessed 28/03/2008. (pp.1-2) 
B] Campaign Participants - responses to $\mathrm{CBC}$ campaign:

\#1 response in newspaper (recreated in blogsite) located at

http://www.urbantoronto.ca/showthread.php?t=5271\&page $=5$

accessed 24/04/2008. (p.7)

\#2 response directly to $\mathrm{CBC}$ campaign - located at http://www.cbc.ca/news/inside-

media/200706/post $1 . \mathrm{html}$

accessed 01/04/2008. (p.3)

\#3 response in blogsite - located at http://anthroplogistwannabe.blogspot.com/2007/05/seven-

wonders-of-canada.html

accessed 07/03/2008. (p.1)

\#4 response directly to $\mathrm{CBC}$ website - located at $h t t p: / / w w w . i n s i d e t h e c b c . c o m /$ sevenwonders accessed 28/03/2008. (p.6)

\#5 response in blogsite - located at http://richdeneault.blogspot.com/2007/06/canadian-

broadcasting-corporation-cbc.html.

accessed 01/04/2008. (p.1)

\#6 response in blogsite - located at http://www.waywayup.blogspot.com/2007/05/seven-

wonders-of-canada.html.

accessed 14/05/2008. (p.2)

\#7 response directly to $\mathrm{CBC}$ website - located at http://www.insidethecbc.com/sevenwonders accessed 28/03/2008. (p.5)

\#8 response in newspaper - located at http://www.thestar.com/printArticle/222321

accessed 28/03/2008. (p.1)

\#9 response in blogsite - located at http://anthroplogistwannabe.blogspot.com/2007/05/sevenwonders-of-canada.html accessed 07/03/2008. (p.1)

\#10 response in blogsite - located at http://www.stevemegan.blogspot.com/2007/06/ohcanada.html accessed 24/04/2008. (p.2)

\#11 response directly to $\mathrm{CBC}$ campaign - located at http://www.cbc.ca/news/insidemedia/200706/post 1.html accessed 28/03/2008. (p.3)

\#12 response directly to CBC website - located at http://origin.www.cbc.ca/sevenwonders/wonder cypress hills.html accessed 28/03/2008. (p.1) 
\#13 response in blogsite - located at http://www.urbantoronto.ca/showthread.php?t $=5271$ \&page $=5$

accessed 24/04/2008. (p.2)

\#14 response in blogsite - located at http://www.ottertooth.com/discus/messages/25/7112.html?1181668814 accessed 28/03/2008. (p.2)

\#15 response directly to CBC website - located at http://www.cbc.ca/sevenwonders/wonder the rockies.html accessed 28/03/2008. (p.2)

\#16 response in blogsite - located at http://richdeneault.blogspot.com/2007/06/canadianbroadcasting-corporation-cbc.html. accessed 01/04/2008. (p.5)

\#17 response directly to $\mathrm{CBC}$ campaign - located at http://www.insidethecbc.com/7flawedwonders accessed 28/03/2008. (p.7) same participant as \#34.

\#18 response in blogsite - located at http://www.ospreyblogs.com/wordpress/?p=472 accessed 28/03/2008. (p.2)

\#19 response in blogsite - located at http://www.ospreyblogs.com/wordpress/?p=472 accessed 28/03/2008. (p.2)

\#20 response in blogsite - located at http://www.stevemegan.blogspot.com/2007/06/ohcanada.html accessed 24/04/2008. (p.1)

\#21 response directly to CBC campaign - located at http://www.cbc.ca/news/insidemedia/200706/post 1.html accessed 28/03/2008. (p.9)

\#22 response directly to $\mathrm{CBC}$ campaign - located at http://www.cbc.ca/news/insidemedia/200706/post $1 . \mathrm{html}$ accessed 28/03/2008. (p.9)

\#23 response directly to $\mathrm{CBC}$ website - located at http://www.cbc.ca/news/insidemedia/2007/06/post 1. html accessed 01/04/2008. (p.5) 
\#24 response at CTC Media Centre - located at http://www.corporate.canada.travel/en/ca/mediacentre/story ideas/lists/7 wonders.html accessed 28/03/2008. (p.1)

\#25 response in blogsite - located at http://www.stevemegan.blogspot.com/2007/06/ohcanada.html accessed 24/04/2008. (p.1)

\#26 response in a newspaper (quoted at $\mathrm{CBC}$ website) - located at http://www.insidethecbc.com/7flawedwonders accessed 28/03/2008. (p.1)

\#27 response in blogsite - located at http://www.stevemegan.blogspot.com/2007/06/ohcanada.html accessed 24/04/2008. (p.1)

\#28 response in blogsite - located at http://richdeneault.blogspot.com/2007/06/canadianbroadcasting-corporation-cbchtml. accessed 01/04/2008. (p.5)

\#29 response in blogsite - located at http://clipmarks.com/clipmark/DAC3A3CF-7C4D-4E8DBCC1-E23766E394C9/ accessed 11/04/2008. (p.3)

\#30 response directly to $\mathrm{CBC}$ - located at http://www.cbc.ca/sevenwonders/wonder pier $21 . h t m 1$ accessed 28/03/2008. (p.2)

\#31 response in newspaper website using promotional material from the museum - located at http://www.halifax.metronews.ca/index.cfm?sid $=61739 \& \mathrm{sc}=422$ accessed 28/03/2008. (p.1)

\#32 response in newspaper website using promotional material from the museum - located at http://www.halifax.metronews.ca/index.cfm?sid $=61739 \& \mathrm{sc}=422$ accessed 28/03/2008. (p.1)

\#33 response directly to $\mathrm{CBC}$ - located at http://www.cbc.ca/sevenwonders/wonder_pier $21 . \mathrm{html}$ accessed 28/03/2008. (p.2)

\#34 response directly to CBC campaign - located at http://www.cbc.ca/news/insidemedia/200706/post $1 . \mathrm{html}$ accessed 28/03/2008. (p.5)

\#35 response in blogsite - located at http://www.stevemegan.blogspot.com/2007/06/ohcanada.html 
accessed 24/04/2008. (p.2)

\#36 response in blogsite - located at http://www.stevemegan.blogspot.com/2007/06/oh-

canada.html

accessed 24/04/2008. (p.3) same person as \#18

\#37 response directly to CBC campaign - located at http://www.cbc.ca/news/inside-

media/200706/post 1.html

accessed 28/03/2008. (p.6)

\#38 response directly to CBC campaign - located at http://www.cbc.ca/news/inside-

media/200706/post $1 . \mathrm{html}$

accessed 28/03/2008. (p.10)

\#39 response directly to $\mathrm{CBC}$ campaign - located at

http://www.insidethecbc.com/7flawedwonders

accessed 28/03/2008. (p.7)

\#40 response directly to $\mathrm{CBC}$ campaign - located at

http://www.insidethecbc.com/7flawedwonders

accessed 28/03/2008. (p.8)

\#41 response in blogsite - located at http://clipmarks.com/clipmark/DAC3A3CF-7C4D-4E8D-

BCC1-E23766E394C9/

accessed 11/04/2008. (p.2)

\#42 response in blogsite - located at http://clipmarks.com/clipmark/DAC3A3CF-7C4D-4E8D-

BCC1-E23766E394C9/

accessed 11/04/2008. (p.2)

\#43 response directly to CBC campaign - located at http://www.cbc.ca/news/inside-

media/200706/post 1.html

accessed 28/03/2008. (p.8)

\#44 response directly to CBC campaign - located at

http://www.insidethecbc.com/7flawedwonders

accessed 28/03/2008. (p.7)

\#45 response in blogsite - located at http://clipmarks.com/clipmark/DAC3A3CF-7C4D-4E8D-

BCC1-E23766E394C9/

accessed 11/04/2008. (p.2)

\#46 response directly to CBC campaign - located at http://www.cbc.ca/news/inside-

media/200706/post $1 . \mathrm{html}$

accessed 28/03/2008. (p.6) 


\section{References:}

Abu-Laban, Yasmeen. (2002). Liberalism, Multiculturalism and the Problem of Essentialism. Citizenship Studies, 6(4), 459-482.

Alba, Richard. (1999). Immigration and the American Realities of Assimilation and Multiculturalism. Sociological Forum, 14(1), 3-25.

Anderson, Benedict. (1991). Imagined Communities: Reflections on the Origin and Spread of Nationalism. New York: Verso.

Angus, Ian. (1997). A Border Within: National Identity, Cultural Plurality, and Wilderness. Montreal: McGill-Queen's Press.

Bannerji, Himani. (2000). On the Dark Side of the Nation: Politics of Multiculturalism and the State of 'Canada'. In The Dark Side of the Nation: Essays on Multiculturalism, Nationalism and Gender (pp. 87-125). Toronto: Canadian Scholars Press.

Bauman, Zygmunt. (1992). Soil, Blood and Identity. The Sociological Review, 40(4), 675-701.

Berger, Carl. (1997). The true north strong and free. In Elspeth Cameron (Ed.), Canadian Culture: An Introductory Reader. (pp. 3-26). Toronto: Canadian Scholar Press.

Bhabha, Homi K. (1990). DissemiNation: Time, Narrative and the Margins of the Modern Nation. In Homi K. Bhabha_(Ed.), Nation and Narration. (pp. 291-322). London; New York: Routledge.

Bissoondath, Neil (1994). Selling Illusions - The Cult of Multiculturalism in Canada. Toronto: Penguin Books

Bonilla-Silva, Eduardo. (2000). 'This is White Country': The Racial Ideology of the Western Nations of the New World-System. Sociological Inquiry, 70(2), Spring, 188-214.

Brodie, Janine. (2002). Citizenship and Solidarity: Reflections on the Canadian Way. Citizenship Studies, 6(4), 377-394

Brooks, Abigail. (2002). Untitled review of Dorothy Smith's lecture series at Boston College March 12-14, 2002. Retrieved 29/12/2008 from

http://www.bc.edu/schools/cas/sociology/vss/smith.html

Burrows, John. (2001). 'Landed' Citizenship: Narratives of Aboriginal Participation. In Will Kymlicka and Wayne Norman (Eds.), Citizenship in Diverse Societies. (pp. 326-344). Oxford University Press. 
CBC Annual Report. (2002-2003). CBC/Radio Canada Annual Report on the Operation of the * Canadian Multiculturalism Act. Retrieved 27/05/2008 from http://www.cbc-radiocanada.ca/docs/equity/multi0203.shtml

CBC Corporate Policies. CBC/Radio Canada Corporate Policies 1.1 Program Policy 1.1.1. CBC Mandate 06/07/1994. Retrieved 21/05/2008 from http://www.cbc.radiocanada.ca/docs/policies/program/mandate.shtml

Cohen, Robin. (1977). "Diasporas in the Age of Globalization", in Global Diasporas: an Introduction. (pp.155-176) Seattle: University of Washington Press

Coleman, Daniel. (2006). White Civility: The Literary Project of English Canada. (pp. 3-45). University of Toronto Press.

Coulombe, Pierre A. (2001), Citizenship and Official Bilingualism. In Will Kymlicka and Wayne Norman (Eds.), Citizenship in Diverse Societies. (pp. 273-293). Oxford University Press.

Erickson, Bruce. (2008). Canoe Nation: Canoes and the Shifting Production of Space Through White Canadian Masculinities. Antipode 40(1), 182-184. Published online 14/02/2008. Retrieved 17/07/2008 from http://www.antipode-online.net

Francis, Daniel. (1997). National Dreams: Myth, Memory and Canadian History. Vancouver: Arsenal Pulp Press.

Golitsinski, Sergei. (2007). Significance of the general public for public relations: A study of the blogosphere's impact on the October 2006 Edelman/Walmart crisis. Unpublished master's thesis. University of Northern Iowa, Cedar Falls, IA. Retrieved 01/01/2009 from http:lordoftheweb.com/thesisma/method.php

Gwyn, Richard. (1995). Nationalism without Walls: The Unbearable Lightness of Being Canadian. Toronto: McClelland \& Stewart.

Hage, Ghassan. (1998). White Nation: Fantasies of White supremacy in a multicultural society. Annandale: Pluto Press Australia

Hall, Stuart. (1993). Cultural Identity and Diaspora. In Patrick Williams and Laura Chrisman (Eds.), Colonial Discourse and Post-Colonial Theory: A Reader. (pp. 392-403). Hertfordshire: Harvester Wheatsheaf.

Henderson, James [Sakej] Youngblood. (2002). Sui Generis and Treaty Citizenship. Citizenship Studies, 6(4), $415-440$.

Herring, Susan C., Kouper, Inna, Papillo, John C., Scheidt, Lois Ann., Tyworth, Michael, Welsh, Peter et al. (2005). Conversations in the Blogosphere: An Analysis "From the Bottom Up". Proceedings of the Thirty-eighth Hawaii International Conference on System Sciences (HICSS- 
38). Los Alamitos: IEEE Press. retrieved 2912/2008 from

http://www.blogninja.com/hicss05.blogconv.pdf

Jackubowski, Lisa Marie. (1997). Controlling Immigration: 'Race' and Canadian Immigration Law and Policy Formation. In Immigration and the Legalization of Racism. (pp. 10-22). Halifax: Fernwood Publishing.

Juteau, Danielle. (2002). The Citizen Makes an Entrée: Redefining the National Community in Quebec. Citizenship Studies, 6(4), 441-458.

Kaplan, David H. (1994). Two Nations in Search of a State: Canada's Ambivalent Spatial Identities. Annals of the Association of American Geographers, 84(4), 585-606.

Kaufman, Eric. (1998). Naturalizing the Nation: The Rise of Naturalistic Nationalism in the United States and Canada. Comparative Studies in Society and History, 40, 666-695.

Kelley, Ninette and Trebilcock, Michael. (2000). The Making of the Mosaic: A History of Canadian Immigration Policy. Toronto: University of Toronto Press.

Kymlicka, Will. (2000). Introduction in Will Kymlicka and Wayne Norman_(Eds.), In Citizenship in Diverse Societies. (pp. 1-44). Oxford University Press.

Kymlicka, Will. (2004). Foreword in James A. Banks (Ed.), Diversity and Citizenship Education - Global Perspectives. San Francisco: Jossey-Bass

Leshinski, Guy. (1998). "Fortress CBC". Ryerson Review of Journalism. Retrieved 07/09/2008 from http://www.rrj.ca/issue/1998/summer/269/

Lopicic, Vesna. (2002). I Dreamed of Canada - Ambivalence in Serbian Attitude to Canada. FACTA UNIVERSITATIS - Series: Linguistics and Literature, 2, 327-334.

Lorenz, Chris. (2001). Towards a theoretical framework for comparing historiographies: some preliminary considerations. Paper presented for the Workshop 'Canadian Historical Consciousness in an International Context: Theoretical Frameworks', Peter Wall Institute for Advanced Studies, UBC, Vancouver, BC, 26-28 August 2001. Retrieved 22/01/2008 from http://www.cshc.ubc.ca/pwias/viewabstract.php?2

Lutz, Harmut. (2004). Race or Place? The Palimpsest of Space in Canadian Prairie Fiction, from Salverson to Cariou. Textual Studies in Canada, 17, 171-185.

Mackey, Eva. (2000). Death by landscape: race, nature, and gender in Canadian nationalist mythology. Canadian Women Studies, 20(2), Summer, 125-137.

Mackey, Eva. (2002). The House of Difference: Cultural Politics and National Identity in Canada. University of Toronto Press. 
Manning, Erin. (2000). 'I Am Canadian': Identity, Territory and the Canadian National Landscape. Theory and Event, 4(4) 1-28.

Millard, Gregory, Reigel, Sarah and Wright, John. (2002). Here's Where We Get Canadian: English-Canadian Nationalism and Popular Culture. The American Review of Canadian Studies, Spring, 11-34.

Mootoo, Shani. (2005). He Drown She in the Sea. Toronto: McClelland \& Stewart

Mukherjee, Bharati. (1996). Beyond Multiculturalism: Surviving the Nineties. Journal Of Modern Literature, 20(1), Summer, 29-35.

Nakajima, Shinsuke, Tatemura, Junichi, Hino, Yoichiro, Hara, Yoshinori and Tanaka, Katsumi. (2005). Discovering Important Bloggers based on Analyzing Blog Threads. WWW2005, May 10-14, 2005, Chiba, Japan. Retrieved 29/12/2008 from www.blogpulse.com/papers/2005/nakajima.pdf

Nurse, Andrew. (2002) Rethinking the Canadian Archipelago: Regionalism and Diversity in Canada. Report prepared at the request of Canadian Heritage. Retrieved 18/09/2008 from http://www.mta.ca/faculty/arts/canadian studies/anurse/regionalism.pdf

Osborne, Brian S. (2001). Landscapes, Memory, Monuments, and Commemoration: Putting Identity in Its Place. Retrieved 07/01/2008 from http://epe.lacbac.gc.ca/100/200/300/citizenship and immigration canada metropolis/landscapes memorye/putinden.pdf

Osborne, Brian. (2006). From Native Pines to Diasporic Geese: Placing Culture, Setting Our Sites, Locating Identity in a Transnational Canada. Canadian Journal of Communication, 31, 147-175.

Peake, Linda and Ray, Brian. (2001). Racializing the Canadian Landscape: Whiteness, Uneven Geographies and Social Justice. The Canadian Geographer, 45(1), 180-186.

Razack, Sherene. (2002). When Place Becomes Race. In Race, Space and the Law: Unmapping a White Settler Society. (pp. 1-20). Toronto: Between the Lines Press.

Shields, Rob. (1991). Places on the Margin. London: Routledge

Stasiulis, Daiva. (2002). Introduction: Reconfiguring Canadian Citizenship. Citizenship Studies, 6(4), 365-375.

Strong-Boag, Veronica. (1994). Contested Space: The Politics of Canadian Memory. Journal of the Canadian Historical Society, 6, 2-17

Taylor, Charles. (1992). Multiculturalism and the 'Politics of Recognition': An Essay. (pp. 2573). Princeton University Press. 
Taylor, Charles. (1993). Shared and Divergent Values. In Reconciling the Solitudes: Essays on Canadian Federalism and Nationalism. (pp.155-186). Montreal and Kingston: Mc-Gill-Queen's University Press. 